\title{
Analysis of banana and cocoa export commodities in food system transformation, with special reference to certification schemes as drivers of change
}

\author{
Carlos F. B. V. Alho ${ }^{1}$ (1) - Amanda F. da Silva ${ }^{2}$. Chantal M. J. Hendriks ${ }^{1}$. Jetse J. Stoorvogel ${ }^{3} \cdot$ Peter J. M. Oosterveer $^{2}$. \\ Eric M. A. Smaling ${ }^{1}$
}

Received: 15 March 2021 / Accepted: 12 August 2021 / Published online: 13 October 2021

(c) The Author(s) 2021

\begin{abstract}
Food systems analysis is increasingly being applied to understand relations between production, distribution, and consumption of food products, the drivers that influence the system, and the outcomes that show how well the food system performs on health and nutrition, on environmental sustainability, and on income and inclusiveness. Little attention has gone to the position of global export commodities, where production and consumption are far apart. Banana in Costa Rica and cocoa in Cote d'Ivoire were the subject of this study to find out what major drivers determine the functioning of these systems. Next to identifying drivers such as population growth and increased plant disease pressure, it was found that the typical far-away setting and different living conditions between producer and consumer countries required a special eye on governance as a tripartite arena (government, private sector, civil society) with their power relations, and on certification schemes as a driver that follows from corporate social responsibility. The certification schemes addressed cover all food system outcomes, although health and nutrition in a less conspicuous way. The descriptions of the functioning of the schemes were also linked to living wages and incomes for banana plantation workers in Costa Rica and cocoa smallholder farmers in Côte d'Ivoire. Although very meaningful, certification schemes so far do not prove to be a silver bullet, but they do have the potential, in combination with other measures, to help positive food system transformations.
\end{abstract}

Keywords Food systems $\cdot$ Banana $\cdot$ Cocoa $\cdot$ Certification $\cdot$ Living income $\cdot$ Living wage

\section{Introduction}

This article belongs to the Topical Collection: Food System Transformations for Healthier Diets, Inclusive Livelihoods and Sustainable Environment

Guest Editors: Romina E Cavatassi, Leslie Lipper, Ruerd Ruben, Eric Smaling, Paul Winters

Carlos F. B. V. Alho

carlos.brazaovieiraalho@wur.nl

1 Wageningen Environmental Research, Wageningen University and Research, PO Box 47, 6700 AA Wageningen, The Netherlands

2 Environmental Policy Group, Wageningen University and Research, PO Box 8130, 6700 EW Wageningen, The Netherlands

3 Soil Geography and Landscape Group, Wageningen University and Research, PO Box 47, 6700 AA Wageningen, The Netherlands
Maintaining global food security will become increasingly challenging in the decades ahead. It is not only human population growth that turns this into a daunting task, but also the need to provide more healthy and nutritious food, the need to distribute food in an affordable and inclusive manner, and the need to maintain the productive capacity of natural resources while mitigating and adapting to climate change. Of late, much attention has gone to the analysis of food systems that try to tackle the functioning of (i) food production; (ii) distribution and (iii) consumption of food products in a holistic manner (Béné et al., 2019; HLPE, 2017; Ingram, 2011; van Berkum et al., 2018). Figure 1 shows the conceptual framework of food systems proposed by Béné et al. (2019), which exhibits a set of drivers related to (i) food supply; (ii) trade and (iii) demand, and a set of outcomes that are related to sustainability, nutrition, efficiency and inclusiveness. The aim of applying a food system approach is not just to depict 


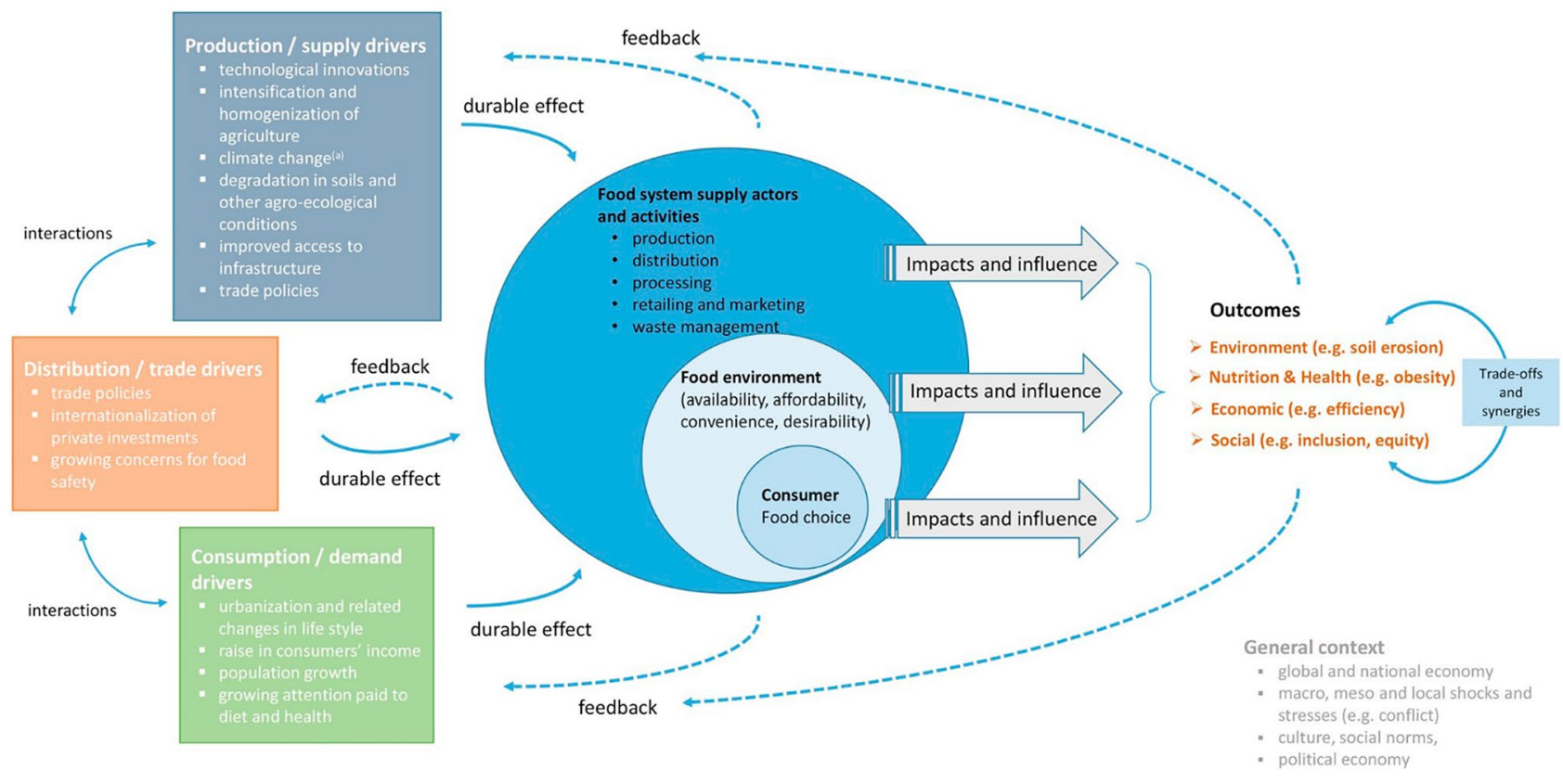

Fig. 1 Conceptual framework of food systems proposed by Béné et al. (2019)

the status quo, but also to see how food systems can be transformed to become more sustainable, healthy, efficient and inclusive. The conceptualization of food systems is progressing rapidly, but a lack of clarity on definitions still limits our understanding of food system drivers (Béné et al., 2019). Nonetheless, the driver groups given are entry points for change and transformation, for using policies, investments or ways to influence consumer behaviour. On the way to a transformation of food systems, there can be trade-offs and synergies between the different outcome groups, and here the challenge is to steer change towards synergies.

A special case is where food production and consumption take place in different continents, and where distribution therefore relies on global trade. In particular, where it concerns export commodities that are produced in developing countries in tropical hemispheres, but of which a large share ends up in the hands and mouths of consumers in higherincome countries. Over past decades, global trade of food products has increased substantially and today about one quarter of food products is traded internationally (Odorico et al., 2014). Therefore, trade is an important aspect to be taken into consideration in analysis of food system transformations (van Berkum et al., 2021). If more than $60 \%$ of a country's total value in exports is driven by commodities, the country is defined as commodity-dependent. High degrees of commodity-dependence are found in Sub-Saharan Africa (41\%) and Latin America and the Caribbean (17\%), mainly covering agricultural products (UNCTAD, 2019). Global commodity trade has contributed to the economy and livelihoods of producing countries as well as to dietary diversity in consuming countries. But it has also contributed to the decoupling of food production and consumption, and the displacement of environmental and socio-economic impacts from food consumption (Kummu et al., 2020). In present debates on sustainable food provision, eating locally is often presented as an optimal strategy (short chains, slow food). This notion leans strongly on the view that long-distance trade of agricultural products is responsible for a large share of global carbon emissions. The evidence is however quite mixed and differs strongly between food groups and products (Poore \& Nemecek, 2018). Moreover, by eating locally, consumers in developed countries may remove businesses, workers and smallholders in developing countries that depend on export commodities for their livelihoods and economies.

Even though the conceptual framework in Fig. 1 is explicit about food system drivers and outcomes, it lacks explicit mention of the power relations in food governance. This is somewhat covered in the blue and grey circles of Fig. 1, but governance is of particular importance in the case of export commodities. This is due to the distance between producer and consumer, and also to market concentration whereby a small number of private companies control global trade. This has raised questions concerning power imbalances in global value chains (Howard, 2016). Also, commodity dependence has been shown to be negatively correlated with the human development index (Nkurunziza et al., 2017). Moreover, the physical distance between production and consumption has also triggered growing concern among consumers in higher-income countries about environmental degradation, 
low wages and income and pesticide-related health risks for primary producers in developing countries (Boström et al., 2019). Companies have reacted to these realities with the concept of Corporate Social Responsibility (CSR) in order to develop sustainable value chains. An instrument to get there, which is classified as a driver in Fig. 1, is the implementation of certification schemes. Here, civil society in importing countries (often through NGOs) speaks to governments and the private sector across global value chains. Certification schemes can address environmental as well as socio-economic food system outcomes and create a linkage between "consumer's responsible choices with producer's responsible practices" (Lee, 2009). Over last decades, certification schemes have been increasingly applied in the export sectors of tropical commodities, such as in the case of banana (Voora et al., 2020) and cocoa (Voora et al., 2019) to endorse more sustainable practices and promote socioeconomic changes.

Food system analysis so far does not explicitly look at the role of export commodities. Therefore, we aimed at analysing two global export commodities (banana and cocoa) through the food system lens of Fig. 1. Compartments, drivers and outcomes are described painting a picture of the position of the commodities in global food systems. The two commodities were chosen because they differ in many respects (Costa Rica vs. Cote d'Ivoire, plantation vs. smallholder systems, market organization, price setting, labour organization, level of processing, relevant drivers), but also in terms of governance which is not covered very explicitly in Fig. 1. Through societal triangulation, the relative position of government, private sector and civil society is pictured for the two commodities. Then, the driver 'certification schemes', being a reflection of governance concerns, is described. Finally, an analysis is done on how certification impacts a living wage (for plantation workers in Costa Rica) and living income (for smallholder cocoa farmers in Cote d'Ivoire) to find out whether this driver contributes to the desirable transformation of food systems.

\section{Methods}

Country data for Costa Rica and Cote d'Ivoire were obtained to paint the geographical picture of the countries of origin, and the relative importance of banana and cocoa for the economies. The analysis of the compartments, drivers and outcomes for banana and cocoa in the two countries was largely based on FAOSTAT (FAO, 2020), other statistical data and on extensive literature review. This also contributed to depicting the societal triangulation (Czischke et al., 2012), where the relationships between government, private sector and civil society become visible. By choosing "certification' as the driver of relevance, the realities surrounding governance focus on this issue. Data sets from NGOs and literature on certification was used to calculate the relative importance in the two sectors. Comparing with and without situations was used to determine whether certification had a positive effect on living wages and income.

\section{Comparing the banana and cocoa export sectors}

Figure 2 presents production, export and import figures for banana and cocoa in 2018. Costa Rica is the third largest exporter of banana and Côte d'Ivoire the first exporter of cocoa. For banana production, Costa Rica is not a major player, but again Côte d'Ivoire is the leader in the world for cocoa production. More than half of the global cocoa production and export is from Côte d'Ivoire and neighbouring Ghana. The United States of America is by far the biggest importer of bananas and The Netherlands of cocoa. For both commodities, The Netherlands and Belgium occur in the top-10 of importers as well as exporters, but typically also serve the European hinterland via their ports.

Bananas directly follow after the major crops wheat, rice and maize in terms of global production (Perrier et al., 2011). Bananas (including plantains) are a key staple food and source of income for millions of people in many tropical countries (Dale et al., 2017). While Asia and the Pacific lead global production (Voora et al., 2020), highest per capita consumption (exceeding $200 \mathrm{~kg}$ of fresh weight per year) is found in East Africa (Scott, 2021). Banana production for local consumption can be quite different compared with banana production for export. For example, banana production in East and Southern Africa is characterized by smallholder farming systems (often intercropped with coffee), where bananas (matooke) exhibit low yields due to abiotic, biotic and socio-economic stresses (Karangwa et al., 2016). Farmers sell their products at local markets or to middlemen who transport matooke to bigger cities for consumption and processing (e.g., in the beer industry). Conversely, banana production for export in Costa Rica is characterized by large mono-cropped plantations dominated by the Cavendish variety and high input levels of fertilizers and agrochemicals. The banana sector in Costa Rica is economically important for: (i) the government, because the crop contributes to GDP, whereas the government also receives taxes per exported banana box of 18 $\mathrm{kg}$ (SCIJ, 2021); (ii) to citizens, because it generates direct employment for almost 40,000 people on the plantations and to 100,000 persons in the support industry (e.g., agricultural inputs, transport, marketing) (Corbana, 2021); and (iii) for the private sector that exports almost the entire volume of produced bananas, resulting in profits that exceed US\$ 1 billion annually (Workman, 2020). Large shipping and 
Global Share of Top 10 Banana Producers

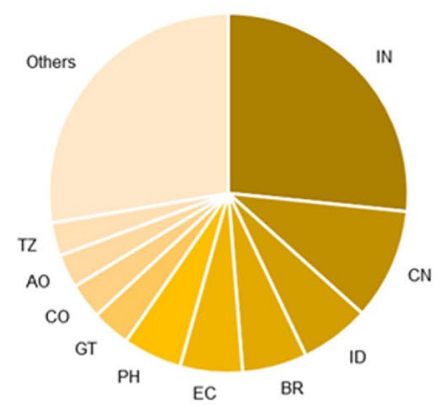

Global Share of Top 10 Banana Exporters

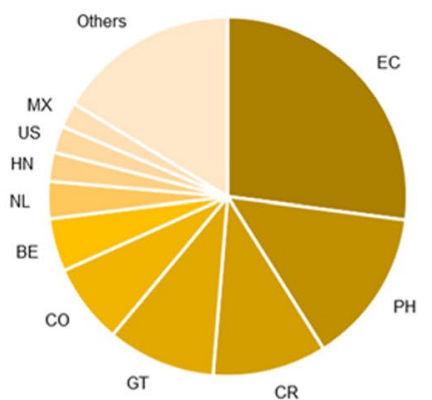

Global Share Top 10 Banana Importers

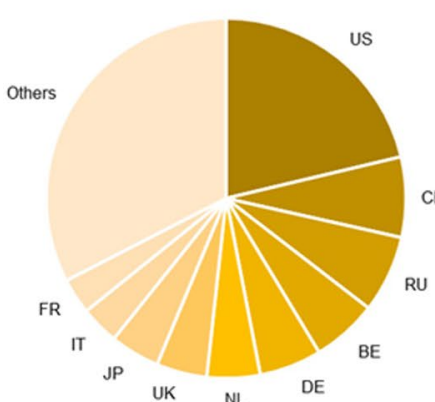

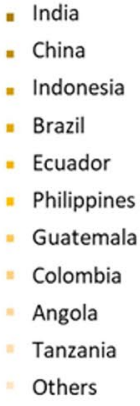

- Ecuador

- Philippines

- Costa Rica

Guatemala

- Colombia

" Belgium

Netherlands

Honduras

United States

Mexico

Others

- United States

- China

- Russia

"Belgium

Germany

Netherlands

United Kingdom

Japan

Italy

France

Others
(IN) $26.6 \%$

(CN) $10.0 \%$

(ID) $\quad 6.3 \%$

(BR) $\quad 5.8 \%$

(EC) $\quad 5.6 \%$

(PH) $\quad 5.3 \%$

(GT) $3.5 \%$

(CO) $3.2 \%$

(AO) $3.0 \%$

(TZ) $\quad 3.0 \%$

$27.6 \%$

(EC) $27.1 \%$

(PH) $\quad 14.0 \%$

(CR) $10.3 \%$

(GT) $9.7 \%$

(CO) $7.2 \%$

(BE) $\quad 4.8 \%$

(NL) $\quad 3.3 \%$

(HN) $2.6 \%$

(US) $\quad 2.4 \%$

(MX) $2.3 \%$

$16.3 \%$

(US) $\quad 21.3 \%$

(CN) $7.2 \%$

(RU) $\quad 6.9 \%$

(BE) $\quad 5.9 \%$

(DE) $\quad 5.6 \%$

(NL) $\quad 4.8 \%$

(UK) $4.6 \%$

(JP) $\quad 4.5 \%$

(IT) $\quad 3.5 \%$

(FR) $\quad 3.2 \%$

$32.6 \%$
Global Share of Top 10 Cocoa Producers

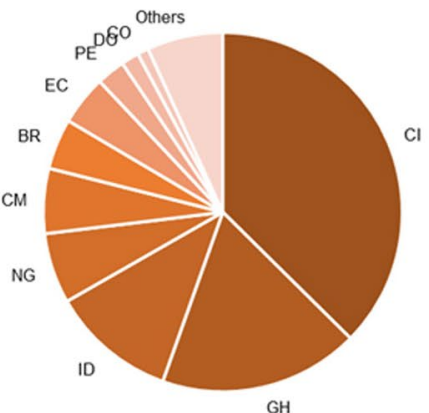

Global Share of Top 10 Cocoa Exporters

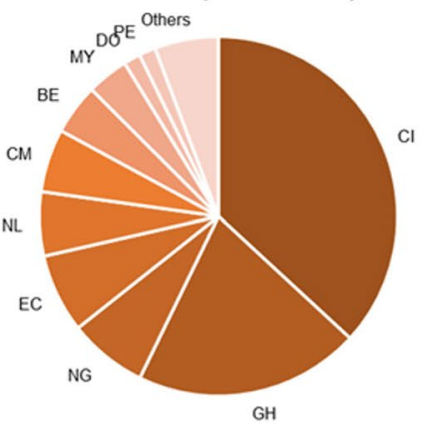

Global Share Top 10 Cocoa Importers

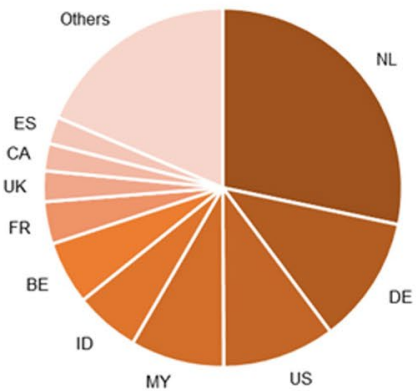

- Netherlands

- Germany

" United States

- Myanmar

" Indonesia

" Belgium

- France

- United Kingdom

Canada

Spain

Others
(CI) $37.4 \%$

(GH) $18.0 \%$

(ID) $11.3 \%$

(NG) $\quad 6.3 \%$

(CM) $5.9 \%$

(BR) $\quad 4.6 \%$

(EC) $\quad 4.5 \%$

(PE) $\quad 2.6 \%$

(DO) $1.6 \%$

(CO) $1.0 \%$

$6.8 \%$

(CI) $36.9 \%$

(GH) $20.4 \%$

(NG) $\quad 7.1 \%$

(EC) $\quad 7.1 \%$

(NL) $\quad 5.7 \%$

(CM) $\quad 5.7 \%$

(BE) $\quad 4.6 \%$

(MY) $\quad 3.8 \%$

(DO) $1.5 \%$

(PE) $\quad 1.5 \%$

$5.8 \%$

(NL) $\quad 28.3 \%$

(DE) $11.5 \%$

(US) $10.2 \%$

(MY) $8.4 \%$

(ID) $\quad 5.9 \%$

(BE) $\quad 5.7 \%$

(FR) $\quad 3.8 \%$

(UK) $2.8 \%$

(CA) $2.5 \%$

(ES) $\quad 2.4 \%$

$18.6 \%$

Fig. 2 Global share (in quantity) of the top 10 banana and cocoa producers, exporters and importers in 2018. Data from FAOSTAT (FAO, 2020)

storage companies are involved in packaging and transporting bananas to the global market. The products must comply with strict food safety regulations set by the major importing countries (the European Union and the United States). The Netherlands is an important player in the ripening, auctioning and redistribution of bananas to the European market, where bananas must meet high quality standards.

Cocoa plantations are mainly located in developing countries in West Africa, Southeast Asia and Latin America (Fountain \& Hütz-Adams, 2020), with around $70 \%$ of the global production coming from millions of smallholders (each with 2-3 ha of land) in West Africa (mainly in Côte d'Ivoire and Ghana) (Thorlakson, 2018). Approximately $5.5 \mathrm{M}$ of smallholder farmers in Côte d'Ivoire and Ghana produce cocoa and they normally earn less than U\$ 1 dollar a day. Cocoa production represents $15 \%$ of the Ivorian GDP, $2 / 3$ of the jobs and half the exports ( $2 \mathrm{M} t$ of cocoa beans per year). The Cocoa Board of the Ivorian government determines the farm gate price every year, which is calculated as a percentage of the London market price and designed to offer a living income to farmers. Since smallholder farmers have no trucks, local traders (pisteurs) take the beans from the farms to the villages and cooperatives. Next in the chain are the traders, who sell the beans to chocolate producers and begin the processing of cocoa beans into cocoa liquor, butter and powder. The Ivorian government gives 100 export licenses per year, which are sold in auction, guaranteeing the tax revenue for the country. Trading and industrial activities are highly concentrated, with three traders/grinders and six brands overly dominating chocolate production worldwide (Thorlakson, 2018). The three traders/grinders dominating the global cocoa market include the Swiss chocolate group 'Barry Callebaut', the American commodities trader 'Cargill' and the agribusiness firm 'Olam', with its 
headquarters in Singapore (Terazono, 2014). Following the same pattern, six brands dominated $60 \%$ of the market for chocolate worldwide in 2016: 'Mars' (14.4\%), 'Mondelez International' (13.7\%), 'Nestlé' (10.2\%), 'Ferrero' (9.5\%), 'Hershey' (7.2\%) and 'Lindt' (5.1\%) (Wunsch, 2021). In summary, the global cocoa chain is basically in the hands of nine companies, making US\$ 100 billion a year. Chocolate companies complain that they are pressured by retailers to keep the price of a chocolate bar low so they keep their spot on their shelves. In an indicative cost breakdown of a milk chocolate bar (where other ingredients are also considered, such as milk and sugar), the cocoa farmer receives between $3.5 \%$ and $6.5 \%$ of the sales price, while traders and manufacturers combined embrace a share of around $50 \%$. Added to that, supermarkets and retailers have a margin of $28 \%$ (Ingram, 2015).

Figure 3 provides several key indicators that allow further comparison of the two commodities. There are major differences in relative export volumes, in price setting, in value chain complexity, in production systems, in the degree of commodity dependence, and in living wage and income.

\section{Food system drivers in the banana and cocoa export sectors}

The banana and cocoa export sectors are under continuous influence by environmental and socioeconomic drivers. They can be categorized as supply (production), trade (distribution) and demand (consumption) drivers (Fig. 1). From this listing, population growth and urbanization are important at a global scale to estimate opportunities for the future expansion of the markets. Cocoa (being more of a luxury product) has a higher income elasticity than banana, leading to different marketing strategies. The internationalization of private investment is relevant for both commodities since a few companies control the global value chains of banana and cocoa. In the case of banana, however, the chain is more straightforward and transparent, and financially less volatile. Food safety concerns are covered by import 'watchdogs' such as the European Food Safety Authority. Infrastructure and information are key to success for both commodities. Bananas require careful harvesting, cable infrastructure in plantations to transport bananas to the packing plant, and a careful packing of green bananas in boxes. Subsequently, climate-controlled shipping and ripening near the markets is essential. Cocoa beans are less perishable since after harvesting the pods are opened and fermented, after which the beans can be extracted, fermented and dried. In Côte d'Ivoire, several levels of middlemen are involved in local transport (on bad roads) and storing and shipping. Thereafter, transport is relatively straightforward, but considerable processing is done, mostly in the importing countries, to produce cocoa-based products. As a result, most of the added value is earned outside the producer countries.

\subsection{Costa Rica: technological innovation (crop breeding), intensification and homogenization (environmental pressure)}

The ongoing spread of Tropical Race 4 (TR4), a major banana disease, threatens the supply of bananas to the global market and the economy and livelihood of bananaexporting countries. Export-based banana plantations in Latin America and the Caribbean (LAC) were previously dominated by the Gros Michel variety, which was suitable for monoculture propagation and long transport routes (FAO, 2019). However, monocultures are susceptible to devastating effects of plant diseases due to limited genetic variation. In fact, Gros Michel plantations were wiped out in the 1950's due to a disease caused by a soil-borne fungus (Fusarium oxysporum f.sp. cubense). To overcome the losses, banana-exporting countries switched to the Cavendish variety, which is currently the main variety grown for export. Even though the Cavendish variety was resistant to what became known as Race 1, this variety is susceptible to the current TR4. Once the soil has been infected with TR4, managing the disease can be extremely challenging and costly. Global loss of production area due to TR4 is predicted to cause 240,000 banana workers to lose their jobs and the countries that suffer the most would be China, the Philippines, Pakistan and Vietnam (in Asia) and Mozambique and Tanzania (in Africa). The negative impact of TR4 in these countries may in turn offer an opportunity for unaffected countries to thrive, most importantly large banana exporters in LAC (FAO, 2019). However, despite the efforts to prevent TR4 to reach LAC, the disease was detected in Colombia in 2019 (Garcia-Bastidas et al., 2019). Given the economic and social importance of banana plantations in the LAC region, the arrival of TR4 imposes a major threat to the economy and livelihood in the region. It has been estimated that total losses to the trade of Gros Michel bananas amounted to a current equivalent of US\$ 2.3 billion and TR4 may cause even greater losses given the current annual value of production for export and the importance of Cavendish bananas (FAO, 2019).

\subsection{Côte d'Ivoire: degradation of soils and agro-ecological conditions}

From the farming perspective there are basically two ways to promote income improvement: either earning more per kilogram of product or increasing the productivity per hectare (Molenaar \& Short, 2018). Until now, yield increases in cocoa farming could be an important strategy for Ivorian smallholders to improve their income and move out of 


\section{EXPORT BANANA}

- Most traded fruit globally and most eaten fresh fruit in the United States and European Union.

- Only grown in the tropics, with only $20 \%$ of global production being exported, of which $80 \%$ comes from Latin America and the Caribbean. Global exports (in 2018) = USD 12 billion.

- Export sector is characterized by large monocropping systems (Cavendish variety), which has been linked with large input of agrochemicals (environmental tradeoff).

- Most countries are not commodity-dependent and most are classified as upper-middle income countries.

- Over $80 \%$ of the global workforce in the banana export industry are men. Especially in areas where working on banana plantations involves migration, the plantations are dominated by male workers. Production tasks differ globally from equal tasks in the Philippines to less physically demanding work in the Caribbean. The wages of woman employees and casual workers are in general lower compared to their male co-workers.

- Straightforward value chain from producers to consumers (unprocessed product). Trade is done by just a handful companies (market concentration).

- Price is not set in international stock markets. Price is marginally volatile (less financial insecurity)

- Increased health awareness $=$ Increased demand for fresh fruit. Increased environmental awareness and social responsibility $=$ Increased demand for sustainable production and fair trade (i.e. certified bananas). Currently, $6-9 \%$ of global production is certified.

\section{EXPORT BANANAS in COSTA RICA}

- $10 \%$ of global share in export quantity (3rd exporter).

- $99 \%$ of production is exported.

- Over USD 1 billion in exports.

- $2 \%$ of GDP and $37 \%$ of agricultural GDP.

- 40,000 direct and 100,000 indirect jobs.

- In Costa Rica, the ratio of men and women working in the banana export industry is much more equal compared to the rest of the world. However, the production tasks are clear: woman are dominantly working in the packing stations, whereas men do most physically demanding work. Men from surrounding countries migrate to Costa Rica, because they offer better working conditions and wages.

- Living wage benchmark = USD 6.09 per capita per day. Over $50 \%$ of banana workers receive wages above living wage benchmarks, while the remaining receive wages that are $10 \%$ lower than the living wage benchmark .

\section{EXPORT COCOA}

- Main ingredient for chocolate production, which is highly consumed in the United States and European Union, with potential to expand to Asian markets.

- Only grown in the tropics, with over $70 \%$ of global production being exported, of which $70 \%$ comes from West Africa. Global exports (in 2018) = USD 9 billion.

- Export sector is characterized by smallholder farming systems which has historically been linked with deforestation (environmental trade-off).

- Most countries are commodity-dependent and most are classified as lower-middle income countries.

- Agricultural land is dominantly owned by men. This makes women often have a relegated position as unpaid family or casual worker in the cocoa field. Therefore, they have unequal access to training, inputs and education. Women play an important role in the early plant care, fermentation and drying of the cocoa beans, which is crucial for sustainable cocoa yield of high quality. The role of women on in the cocoa fields is increasingly being recognized by international trade companies

- Complex value chain from producers to consumers (highly processed products). Trade and processing are done by just a handful of companies (market concentration).

- Price is set in international stock markets. Price is largely volatile (more financial insecurity).

- Increased health awareness $=$ Increased demand for 'dark' chocolate (higher percentage of cocoa). Increased environmental awareness and social responsibility = Increased demand for sustainable production and fair trade (i.e. certified cocoa). Currently, $23-40 \%$ of global production is certified.

\section{EXPORT COCOA in CÔTE D'IVOIRE}

- $37 \%$ of global share in export quantity (1st exporter).

- $78 \%$ of production is exported (as cocoa beans)

- Over USD 3 billion in exports

- $7 \%$ of GDP and $43 \%$ of agricultural GDP.

- 5 million smallholders.

- In Côte d'Ivoire, only $20 \%$ of the women own an agricultural field and only $4 \%$ of cocoa farmers are woman. The role of women in the cocoa field is not always clear, because reproductive and productive activities run together.

- Living income benchmark (daily) = USD 2.52 per capita per day. Over $90 \%$ of cocoa smallholders are incapable of achieving the living income benchmark.

Fig. 3 Key indicators of the banana and cocoa export sectors, including the cases of export bananas in Costa Rica and export cocoa in Côte d'Ivoire 
poverty without relying on area expansion. Three rejuvenation is an effective agricultural practice to increase yields. However, the lack of knowledge to do so and the use of obsolete agricultural practices in the field restrict the rejuvenation adoption (Dormon et al., 2004). Thus, farmers started growing cocoa illegally in areas that are formally 'protected', where virgin soils offer a possibility to plant new crops. In these more fertile uncultivated areas, cocoa starts to yield in 2-3 years as opposed to 5-6 years in already cultivated areas. Estimations indicate that Côte d'Ivoire has lost $85 \%$ of its forests since 1960 (Aboa, 2021).

\subsection{Greenhouse gas emissions and climate change}

Estimations of greenhouse gas (GHG) emissions throughout the value chain can be useful to understand the carbon footprint of food products and their contribution to climate change. Climate change is also a driver towards dietary changes, which in turn have an effect on GHG emissions (Duku et al., 2021). Figure 4 shows that the banana supply chain results in relatively small quantities of GHG emissions compared to other food products, while GHG emissions from the supply chain of cocoa are relatively high due to forest cutting and the opening up of land resulting in losses of soil carbon and biomass (Boeckx et al., 2020), which contributes to climate change. In turn, climate change is expected to cause negative impacts in the banana and cocoa sectors. Climate change is expected to cause declining yields in banana production potentially impacting global banana markets (Varma \& Bebber, 2019). Future projections on the impacts of climate change on cocoa production in West Africa, indicate that changes in weather patterns, mainly related to temperatures and water availability, might lead to regional shifts towards the south, where cocoa would be better adapted to the changing weather conditions, with potential risks of further deforestation (Schroth et al., 2016).

\subsection{Trade policies in the banana and cocoa export sectors}

Wiley (1998) described the changed market and trade landscape for bananas in 1993 after the European Union (EU) allowed non-ACP countries to take a larger share of the European market. This was also driven by the World Trade Organization, pushing the EU to give up the preferential partnership with its former colonies. Fluctuation in the banana trade is largely due to the seasonality in banana demand (i.e., decreased demand in large markets in summer due to availability of local fruits) and climate-related production challenges (i.e., floods, cooler temperatures and
Fig. 4 Greenhouse gases (GHG) emissions ( $\mathrm{kg} \mathrm{CO}_{2-}$ eq per $\mathrm{kg}$ product) for selected food products. For comparison, bananas and dark chocolate (representative for cocoa) are contrasted with the food products with the largest and lowest GHG emissions (bovine meat and nuts, respectively). Data from Poore and Nemecek (2018)

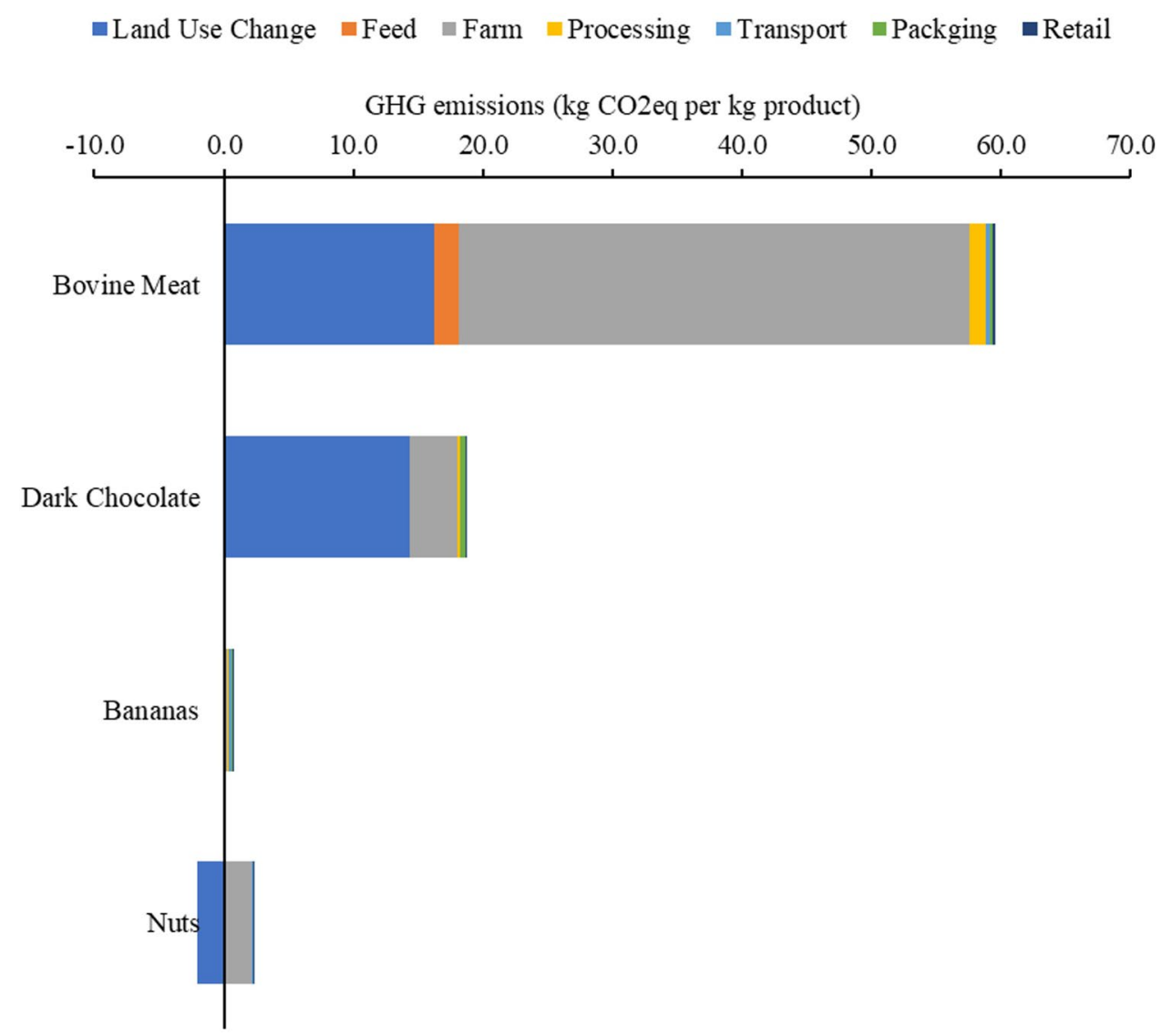


mudslides) (Voora et al., 2020). Bananas are not subject to international mechanisms for price setting. Instead, price differentiation among supply countries is related to factors such as quality and sustainable sourcing (Getz \& Shreck, 2006). The market share of a producing country is determined in an open market and thus basically defined by the product quality with a relatively low price (Fonsah \& Chidebelu, 2011).

The global cocoa price is established on the cocoa futures market based in London and New York (ICCO, 2016). Cocoa prices can be quite volatile due to supply-demand fluctuations, market speculations, investment considerations and currency movements (Agritrade, 2013). For instance, the government in Côte d'Ivoire uses these international benchmarks to determine the minimum farm-gate price locally, which is a result of the price paid at auction for future sales, before the new crop season (Malan, 2013). Through these auctions, between $70-80 \%$ of the production for the next year is sold in advance to exporters. From the final price sold, about $60 \%$ goes to smallholders, while $40 \%$ is retained by the government as taxes (Agritrade, 2013). Although these taxes are very high, there is little transparency on how they are reinvested in the cocoa sector or how they are converted into real benefits for the local population. There is a sentiment that the local elites still benefit unequally from this price control mechanism compared to smallholders (Laven et al. 2016). Moreover, in Côte d'Ivoire, a differentiation in price based on higher quality is not possible because of this price control. However, the payment of certification premiums on top of the established price is still possible (Bymolt et al., 2018).

\subsection{Consumer's income and growing attention to diet and health}

Bananas are an affordable and convenient source of energy, vitamins, minerals and dietary fibre (Voora et al., 2020) and therefore, are difficult to be replaced by other fruits in the global market. Indeed, bananas are the most eaten fresh fruit in the EU and the United States (US) (D'hont et al., 2012). Given its practicality and healthy profile, banana is likely to maintain or slightly increase its position as the favourite fresh fruit in well-established global markets. The banana sector is projected to experience a modest compound annual growth rate (CAGR) of $1.2 \%$ in consumption between 2019 and 2024 (Voora et al., 2020) likely driven by population growth and increasing health awareness.

Cocoa is the main ingredient for chocolate production. Global average chocolate consumption in 2017 was about $0.9 \mathrm{~kg}$ per capita, with a fairly stable consumption in the most important global markets (i.e., EU and US) (CBI, 2019). Commonly, chocolate consumption is larger in high-income countries. In Switzerland, the largest chocolate consumer, chocolate consumption reached $10.5 \mathrm{~kg}$ per capita in 2017 (CBI, 2019). In China and India, chocolate consumption reached only a mere 100-200 g per capita for the same year (StatInvestor, 2021). The cocoa sector is expected to grow at a CAGR of $7.3 \%$ between 2019 and 2025 (Voora et al., 2019), which is most likely driven by an increase in household income in developing countries. China and India are regarded as promising markets due to the rise of the middle class (Food Navigator, 2019). The Chinese market may face constraints given its high prevalence of lactose sensitivity in the population. Moreover, many countries in Asia and the Pacific region are exposed to very high temperatures, which can cause chocolate to melt at room temperatures. Therefore, a rise in chocolate consumption in these areas needs to be accompanied by changes in infrastructure as well as a possible "tropicalization of the recipe" to adapt to the local conditions and also a lowering of the final price (for example, by replacing cocoa butter with cheaper vegetable fats). Furthermore, the global increase in health awareness can be expected to increase the demand for cocoa with high flavanol content (e.g., dark chocolate) (Argout et al., 2011). Consumption of high-flavanol cocoa products has been shown to reduce blood pressure (Davison et al., 2010) and insulin resistance and therefore, reduce the risks to develop cardiovascular diseases (Tokede et al., 2011) and type 2 diabetes (Maskarinec et al., 2019).

\subsection{Corporate social responsibility and certification schemes: measures against environmental and societal concerns}

An issue that is particularly relevant for export commodities is the concerns raised by consumers in importing countries about environmentally unfriendly production systems (e.g., excessive use of pesticides threatening both soil and water, and nearby nature areas) and social misery (e.g., poor human rights, low incomes, and gender inequalities). It is a case where governance is multi-stakeholder (government, private sector, civil society), but also between countries that are far apart, and all pushing for their own interest. One way to arrange the actors is to use a societal triangle (Czischke et al., 2012) and group stakeholders as governmental (G), private sector $(\mathrm{P})$ and civil society $(\mathrm{S})$ actors in bilateral confrontational ways to analyse how theses stakeholders may influence one another. Doing this can lead to more targeted responses to system challenges (Boylan et al., 2019).

Each actor group can use different regulatory means, including subsidies and taxes, import regulations (G), readiness to invest and market concentration $(\mathrm{P})$, labour union activities and the pushing for environmental and socio-economic concerns through media attention, crowdfunding and demonstrations by NGOs (S). Governance is an important aspect to be taken into consideration in analysis of food system transformations (Leeuwis et al., 2021). 
Governance in food systems is of particular importance in the case of export commodities because this is often controlled by a small number of private companies creating market concentration. Moreover, there are no public authorities in charge of regulating the global trade of these internationally traded commodities. In this context, both the banana and cocoa export sectors can be characterized as buyer-driven cases (Fold and Neilson, 2016). This means these large companies have a great power over other stakeholders in the value chain. This is common in cheap and labour-intensive commodity sectors, such as banana and cocoa (Gereffi \& Fernandez-Stark, 2018; Global Value Chains, 2017).

Over time, private corporations have been growing in importance, and this came accompanied with a proportional level of societal responsibility about their decisions (Crane et al., 2008). Companies have reacted to that public agenda with the development of the concept of Corporate Social Responsibility (CSR). This can be firstly understood as a management method by which businesses can achieve a balance between environmental awareness, social responsibility and economic viability in their operations, or, in other words, apply a "triple bottom line approach". By definition, CSR also encompasses the relationships with the relevant stakeholders in that business. On top of this, CSR brings an important focus on morality and ethics within corporations on a voluntary basis, beyond compliance with formal regulations. CSR translates often into certification schemes. These can be regarded as drivers, as they have the power to foster change and endorse more environmentally and socially friendly practices in the producer environment (Maloni \& Brown, 2006).

\section{Certification schemes in the banana and cocoa export sectors}

Certification schemes emerged as a market response for achieving more sustainable and social practices throughout global value chains. Either driven by non-governmental agencies or private organizations, these schemes have been performing an important role in the value chains of export commodities, especially when state regulation is absent (Bush et al., 2013). Certification standards commonly go beyond national regulations and incorporate relevant aspects of both production and trade to promote desirable food system outcomes (Liu et al., 2004). Nonetheless, in a certified buyer-driven chain, the leading companies also establish and regulate the quality of the commodity, define the rules for participating in the chain and determine the division of labour among other actors (Ponte \& Gibbon, 2005). In other words, beyond the consumer's demand which is originated downstream, the producer's decision to be certified often comes as a requirement from powerful companies imposed upon the production base to respond to that demand. This means that producers may not always have a choice whether to comply with certification schemes because they are compelled to follow them in order to have access to attractive global markets.

Certification labels for bananas started primarily under the consumers' pressure for improvements in the environmental profile of intensive production, especially related to the use of pesticides, climate resilience, water usage and the protection of primary forest (Willer et al., 2019). The 'Rainforest Alliance' certification arose as one of the industry's most prominent responses to these demands (Bellamy et al., 2016) and is currently the most widespread label for bananas (Willer et al., 2019). Many other schemes, including 'UTZ', were initiated as a result of the increase in environmental and sustainability awareness experienced over the last decades, with an important focus on deforestation of tropical forests caused by the production of agricultural export commodities (UTZ, 2019, 2020). 'Rainforest Alliance' and 'UTZ' have recently merged and together they are expected to account for $79 \%$ of certified cocoa sales worldwide (Nieburg, 2018).

Over recent decades, certification schemes have been increasingly applied in the banana (Voora et al., 2020) and cocoa (Voora et al., 2019) export sectors to endorse more sustainable practices and promote social-economic changes. These schemes have standards that include indicators about deforestation, control over the use of agrochemicals, climate change mitigation, poverty alleviation, slavery and child labour (Cargill, 2019; Chiquita, 2019; UTZ, 2019). For bananas, it has been estimated that the share of the certified area in 2017 ranged between 6.0 and $9.9 \%$ (mainly covered by 'Fairtrade International', 'GLOBALG.A.P.', 'Organic' and 'Rainforest Alliance'), whereas for cocoa, it has been estimated that the share of the certified area for the same year ranged between 23.4 and $40.8 \%$ (mainly covered by 'Fairtrade International', 'Organic', 'Rainforest Alliance' and 'UTZ') (Willer et al., 2019).

Figure 5 illustrates a societal triangle showing the role of different societal actors in addressing the environmental impact of the banana export sector in Costa Rica. The 'Rainforest Alliance' certification scheme aims to reduce environmental harm caused by banana plantations. Consumers of importing countries increasingly pay attention to certification schemes and therefore many actors show increasing interest in such a scheme. Note that there are also other factors that influence the responsibility of actors. For example, new policies made by the governmental institutions of importing countries also aim to reduce the environmental impact of banana plantations in Costa Rica. Society (including NGO's, employees and citizens) has the responsibility to reflect on the progress made by the private sector and 
Fig. 5 The societal triangle regarding the environmental impact of the banana sector in Costa Rica. All actors, civil society (S), the private sector (P) and the government $(\mathrm{G})$, have a responsibility to meet the goal of reducing environmental harm

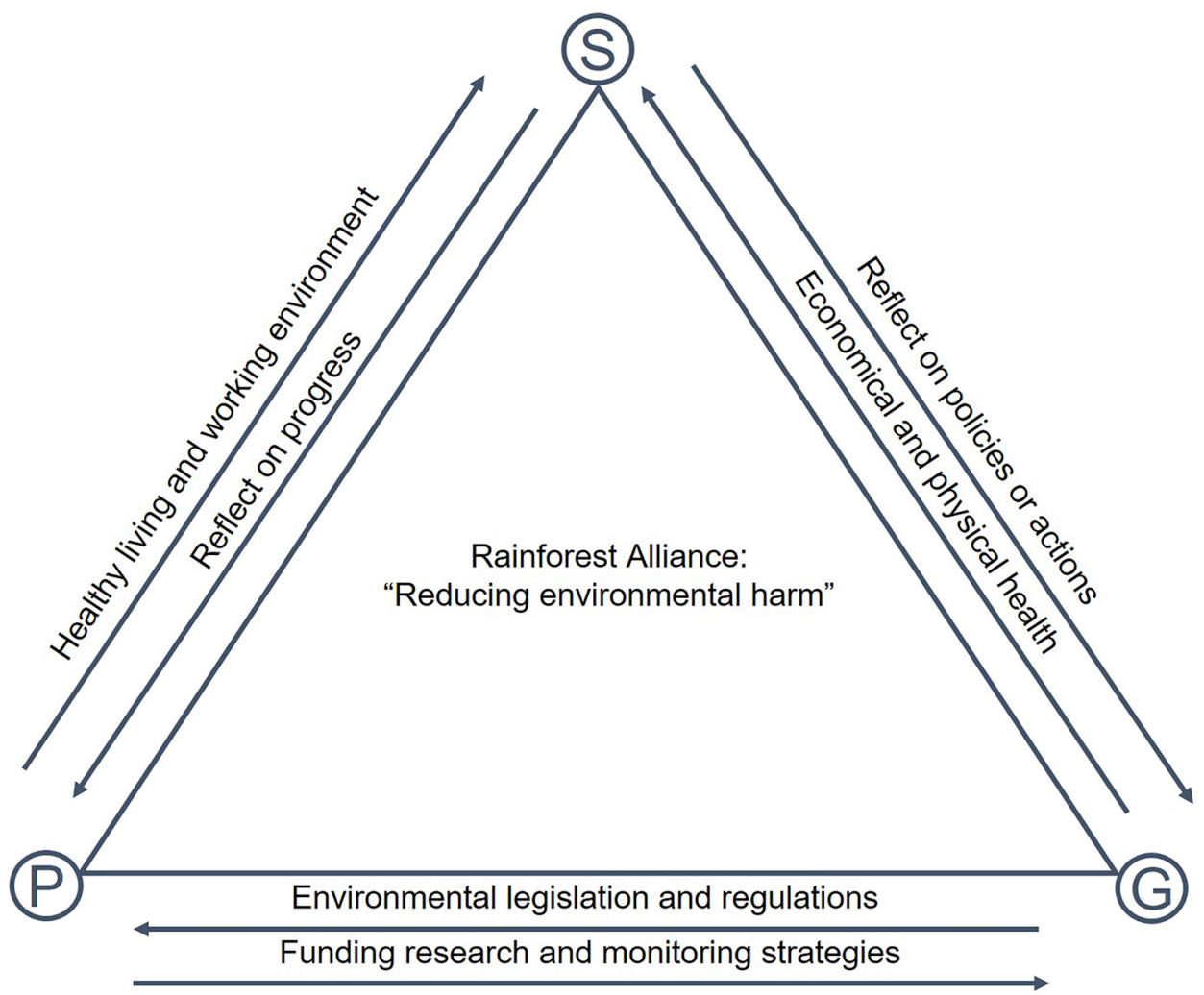

the policies and actions taken by government. The government has the responsibility to keep society economically and physically healthy and therefore needs to formulate environmental legislation and regulations for the private sector. This needs to meet the expectations of society and to comply with the policies of importing countries. The private sector needs to keep society satisfied, which makes them responsible for a healthy living and working environment. But they also need to keep the government updated on their environmental footprint. The private sector in Costa Rica funds research and monitoring as both the government and the private sector have common economic interests. It is interesting to note that people from the private sector also have a position in government.

Figure 6 illustrates the societal triangle addressing child labour in Côte d'Ivoire. Several organizations and certification schemes aim to fight child labour and the 'Fairtrade International' certification scheme is one of them. Several studies reflected on this goal and there seems to be an imbalance in the power distribution between the different actors ( $\mathrm{S}, \mathrm{G}$ and $\mathrm{P})$. The private sector, which includes a small number of multinationals, appear to possess most of the power but have not yet succeeded in reducing the problem of child labour. Even the introduction of the Child Labour Monitoring and Remediation System, that resulted from a collaboration between the multinationals and the International Cocoa Initiative, has not succeeded. To understand why the numbers of child workers are not decreasing, it is necessary to reflect on the role of government. Abandoning child labour in a sustainable way is a responsibility that the government has towards society, but it so far does not seem to deliver. Active engagement of civil society from importing countries can then potentially awaken governments and private companies to take action. The 'fair trade' desire is the power mechanism of civil society, provided there is a public that wants to pay for slavery-free chocolate.

\section{Signs of food system transformations in the banana and cocoa export sectors}

\subsection{Costa Rica: response to environmental and health concerns}

The high pressure of pests and diseases with banana requires producers to make intensive use of agrochemicals (e.g., fungicides and nematicides). In addition, the large uptake of nutrients by the crop requires intensive use of organic and mineral fertilizer (Bellamy, 2013). The effect of intensive use of pesticides and fertilisers has been studied exhaustively. Excessive and careless use of pesticides can have lasting effects on soils, neighbouring ecosystems and humans active in the banana sector. Costa Rica has, however, implemented tough environmental regulations and appears responsive to 
Fig. 6 The societal triangle regarding child-labour in the cacao export sector in Côte d'Ivoire. All actors, civil society $(\mathrm{S})$, the private sector $(\mathrm{P})$ and the government $(\mathrm{G})$, have a responsibility to meet the goal of fighting child labour

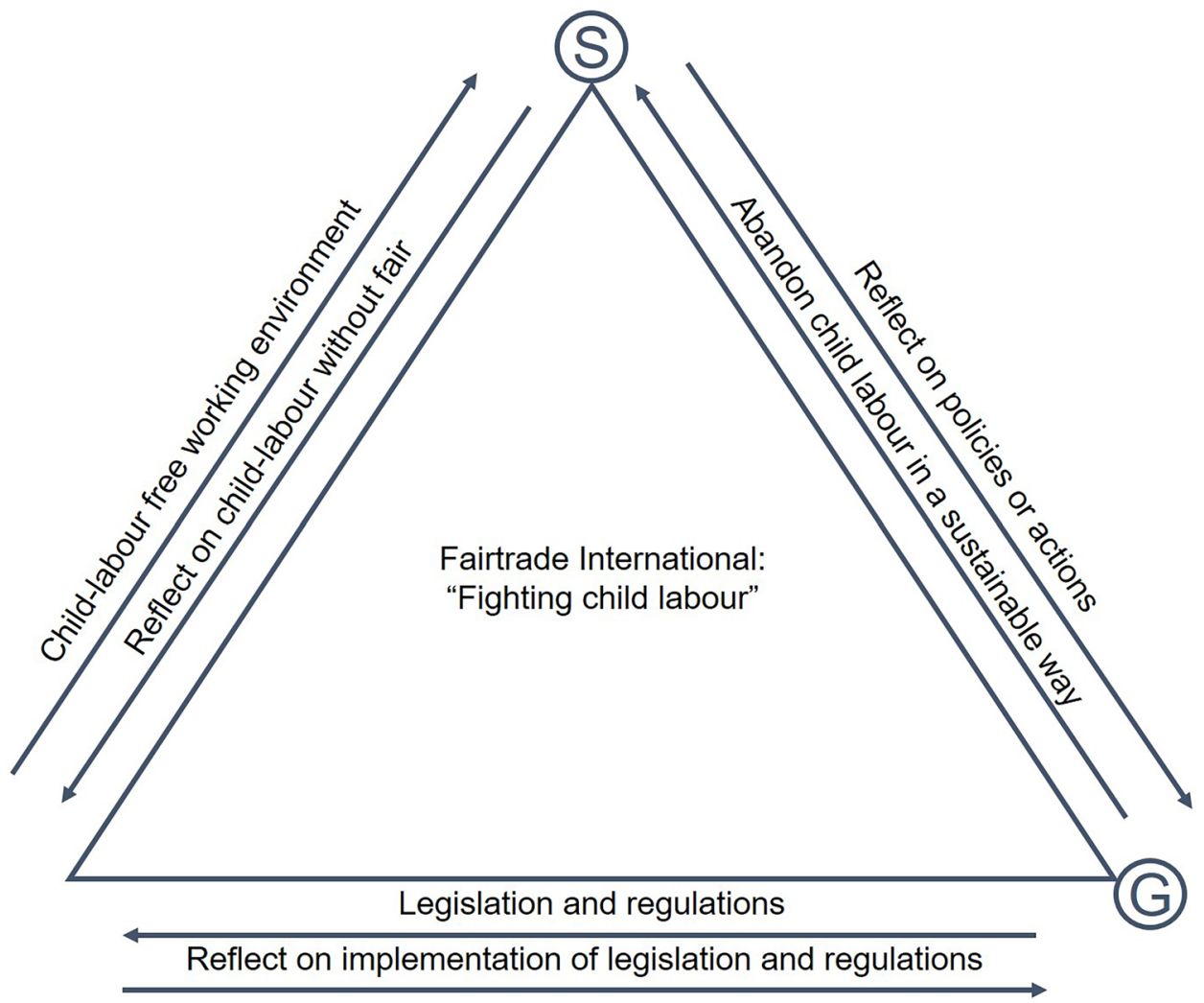

complaints and desires from plantation workers. For exported bananas, regulations are very strict and dictated by bodies such as the European Food Safety Authority. These are generally stricter than local rules (Mendez et al., 2018). Soil toxicity as a result of persistent use of fungicides in former banana plantations was found to severely damage soil quality already some 30 years ago (Thrupp, 1991). Many more recent studies reviewed the effects of pesticide use in bordering nature areas, including wetlands and fish stocks (AriasAndrés et al., 2018; Echeverría-Sáenz et al., 2018; Fournier et al., 2018; Rämö et al., 2018). Over past decades, Costa Rica has progressed in fighting environmental pollution and health hazards for plantation workers. Marquardt (2002) described the powerful labour movement in Costa Rica and how it managed to put the health threats of pesticide use on the negotiation table. Pesticide use has been reduced substantially over the past 30 years, and some pesticides have been banned. Also, Green Chemistry-Based Biocontrol Agents have been developed that have low toxicity, recognized biocompatibility, and a rapid biodegradability (Ureña-Saborío et al., 2017).

\subsection{Côte d'Ivoire: response to deforestation}

Cocoa production is a substantial driver of deforestation in West Africa (Ruf et al., 2015). Evidence shows that the highest peaks in cocoa prices also culminated in high deforestation rates in producing countries (Franzen \& Borgerhoff Mulder, 2007). Among other factors, deforestation also comes as an attempt to offset the low productivity rates faced by farmers, especially in Ghana and Côte d'Ivoire (de Beule et al., 2014). As a consequence, recurrent deforestation has resulted in a drier local climate, which negatively affects the optimal growth for cocoa, given its high humidity requirements (Bymolt et al., 2018). This further contributes to the self-feeding cycle of low yields, deforestation and poverty traps. General awareness on environmental and social issues at the consumers' node has prompted initiatives around the private sector to extinguish deforestation practices, extreme poverty and use of child labour from their supply chain operations (Lambin et al., 2018; Molenaar \& Short, 2018; Thorlakson, 2018). To counterbalance these issues, certification schemes started in the cocoa global value chain. Although much effort has been put into enforcing these certification standards alongside with their growth in area coverage, deforestation practices around cocoa areas are still a reality. As the area of commodity production covered with certification schemes has grown in most of the producing countries, so too has the total area of forest and land being converted to agriculture. This occurs even with clear standards prohibiting conversion of primary forest to agricultural production (van der Ven et al., 2018). Therefore, the real effect of certification schemes in avoiding deforestation is still uncertain. Agroforestry has been lately implemented as a tool to suppress deforestation practices around cocoa areas. Agroforestry can promote a more stable setting because it can 
combine ecological services and biodiversity conservation with a diversified crop production (Vaast et al., 2016). Therefore, agroforestry simultaneously addresses environmental concerns while bringing income resilience and food security to local communities (Speranza, 2013; Jacobi et al., 2015; Makate et al., 2016). In the specific case of cocoa, agroforestry systems come in opposition to conventional, intensive non-shade and homogenous cultivation methods to give rise to a diversified and heterogeneous environment. There, cocoa interacts with additional fruits and forest trees composing a complex and intertwined system (Jagoret et al., 2018). Different aspects determine the plants diversity to be associated with cocoa production in agroforestry systems (e.g. plant domestication, research/extension advice, shade provision, local market landscape, diet patterns, local climate, etc). In West Africa, agroforestry systems are mainly composed of exotic fruits, timber and non-timber species. In Ivory Coast, the cultivation of exotic/edible fruits together with cocoa is the most notable choice in agroforestry, reaching more than $80 \%$ of the additional tree coverage in some regions (Sonwa et al., 2014). The maintenance of shade, despite cocoa intensification systems, gives farmers more environmental resilience to climate change and pest outbreaks, which has local and broader effects (Vaast \& Somarriba, 2014). Cocoa yields can be boosted by up to $50 \%$ if approximately 100 shade trees per hectare were planted in a spatially organized manner, conferring a win-win solution for biodiversity conservation and higher productivity for smallholders (Waldron et al., 2015)

\subsection{Côte d'Ivoire: response to market dominance and child labour}

Through a joint initiative, Ghana and Côte d'Ivoire have recently managed to convince chocolate traders and makers to raise the price of cocoa. The problem is that Africa's cocoa producing countries capture just $4 \%$ of global chocolate industry revenue (Ingram, 2015). Although Côte d'Ivoire produced 2.1 million tonnes of cocoa in 2017 (44\% of global output), it brought in just 3.3 billion US $\$$ from the trade, compared to earnings of 22 billion US\$ for US chocolate majors (Mieu, 2020). In July 2019, the cocoa boards of Côte d'Ivoire and Ghana successfully imposed a pricing mechanism to help producers to earn a living income. As a positive impact, on the subsequent harvest season of 2020/2021, the price paid at the farmer gate was increased by $28 \%$ to US $\$ 1,837$ per $\mathrm{t}$ in Ghana and by $21 \%$ to US $\$ 1,840$ in Côte d'Ivoire (Fountain $\&$ Hütz-Adams, 2020). Although substantial, both values are still not sufficient to help producers earn a living income. As a recent measure, it is still questionable to what extent this new premium ended up in the hands of smallholders. Price control is not new in Côte d'Ivoire and Ghana, and although there has been a minimum farm gate price, much is retained by the local authorities. Ivorian farmers, for example, are among the lowest paid cocoa farmers in the world (Laven et al., 2016).
In the Ivorian context, from the final price sold about $60 \%$ goes to farmers, while $40 \%$ is retained by the government as taxes (Agritrade, 2013). The literature lacks research on how cocoa prices could be effectively enhanced by means other than certification premiums or government control, which raises the question whether these measures help smallholders earn a living income or whether a free market would be a better approach (da Silva, 2020). The issue also lays on the fact that this measure was a decision taken without considering other key stakeholders, lacking the participation of private organizations, farmers unions, and NGOs (Fountain \& Hütz-Adams, 2020). Discussing such an issue without a multistakeholder platform can lead to adverse effects, as history has shown. According to the International Labour Organization in 2005 , more than 200,000 children were working on cocoa farms in Côte d'Ivoire, some of them "in the worst forms of child labour". In 2007, the International Cocoa Initiative launched a campaign to improve the livelihoods of children working in cocoa. However, the number of children working on cocoa farms in Côte d'Ivoire went up to more than 800,000 in $2008-2009$, and to 1.3 million in 2013-2014. In 2018, the VOICE Network, along with a global consortium of civil society organizations, released the Cocoa Barometer 2018, a biennial assessment of the state of the US\$ 100 billion industry. In regard to child labour, the report states, "not a single company or government is anywhere near reaching the sector-wide objective of the elimination of child labour, and not even near their commitments of a $70 \%$ reduction of child labour by 2020." And although the Child Labour Monitoring and Remediation Systems that the International Cocoa Initiative has implemented with industry partners are useful, they are currently reaching less than $20 \%$ of the over two million children impacted. The VOICE network also mentions that while many of the current programs in cocoa focus on technical solutions around improving farming practices, the underlying problems deal with power and political economy; how the market defines price; the lack of power of farmers to bargain and rejuvenate their crop; market concentration of multinationals; and a lack of transparency and accountability of both governments and companies.

\section{Do certification schemes help in the realization of a living wage and a living income?}

From a socio-economic perspective, the incapability of achieving a living wage/income can be understood as an undesirable food system outcome. The concepts of living wage and living income receive increasing attention in interventions for socio-economic development since these concepts incorporate important components that are intrinsically linked to a decent life (van de Ven et al., 2020; Waarts 
et al., 2021). Living wage is defined as "the remuneration received for a standard workweek by a worker in a particular place, sufficient to afford a decent standard of living for the worker and her or his family" (Global Living Wage, 2018). Living income is defined as "the net annual income required for a household in a particular place to afford a decent standard of living for all members of that household" (Living Income, 2019) (Fig. 7). Elements of a decent standard of living include: food, water, housing, education, healthcare, transport, clothing, and other essential needs including provision for unexpected events. Depending on how agricultural activities are conducted and the social relations structured, one of the two concepts might be more applicable than the other. The main distinction between these concepts, is the employment status, which is different for banana and for cocoa. The concept of living wage is more applicable to the case of paid banana plantation workers in Costa Rica, whereas the concept of living income is more applicable to the case of cocoa smallholder farmers in Cote d'Ivoire.

Certification schemes have different approaches when it comes to premiums, which means that these schemes have different impacts on wage/income gaps. For example, 'UTZ-Rainforest Alliance' have a premium called "Sustainability Differential", which is based on a negotiation between farmers and traders and applied to the overall market price (UTZ, 2018), but this is often insufficient to cover the minimum production costs (da Silva, 2020). 'Fairtrade International' has several indicators to calculate the "Cost of Sustainable Production" for certified crops, which then is defined as the "Fairtrade Minimum Price". On top of that, a "Fairtrade Premium" is added and paid to smallholder cooperatives. The overall calculation is context-based, taking into account local particularities, such as where the crop is grown (Fairtrade International, 2020a).

'Fairtrade' certification delivers additional premiums on top of their fixed prices that aim at covering farming costs as well as providing a decent life to growers, in such a way that farmers are capable of reinvesting this money back into the community (Fairtrade International, 2020b). 'Fairtrade' prices are based on local realities, in contrast to 'UTZ-Rainforest Alliance', which base their calculations on market dynamics and negotiations between traders and farmers. Considering the power imbalance between traders and farmers and the low bargaining power that smallholders have when negotiating with companies, a premium that comes as a result of this negotiation might not fully benefit cocoa smallholders. This explains why the biggest certification schemes are often considered insufficient to improve the livelihood of cocoa smallholders (Glasbergen, 2018). Nevertheless, 'Fairtrade' is not without criticisms for its lack of impact and the low engagement of cocoa smallholders in its implementation (Uribe-Leitz \& Ruf, 2019).

\section{The Living Income Story}

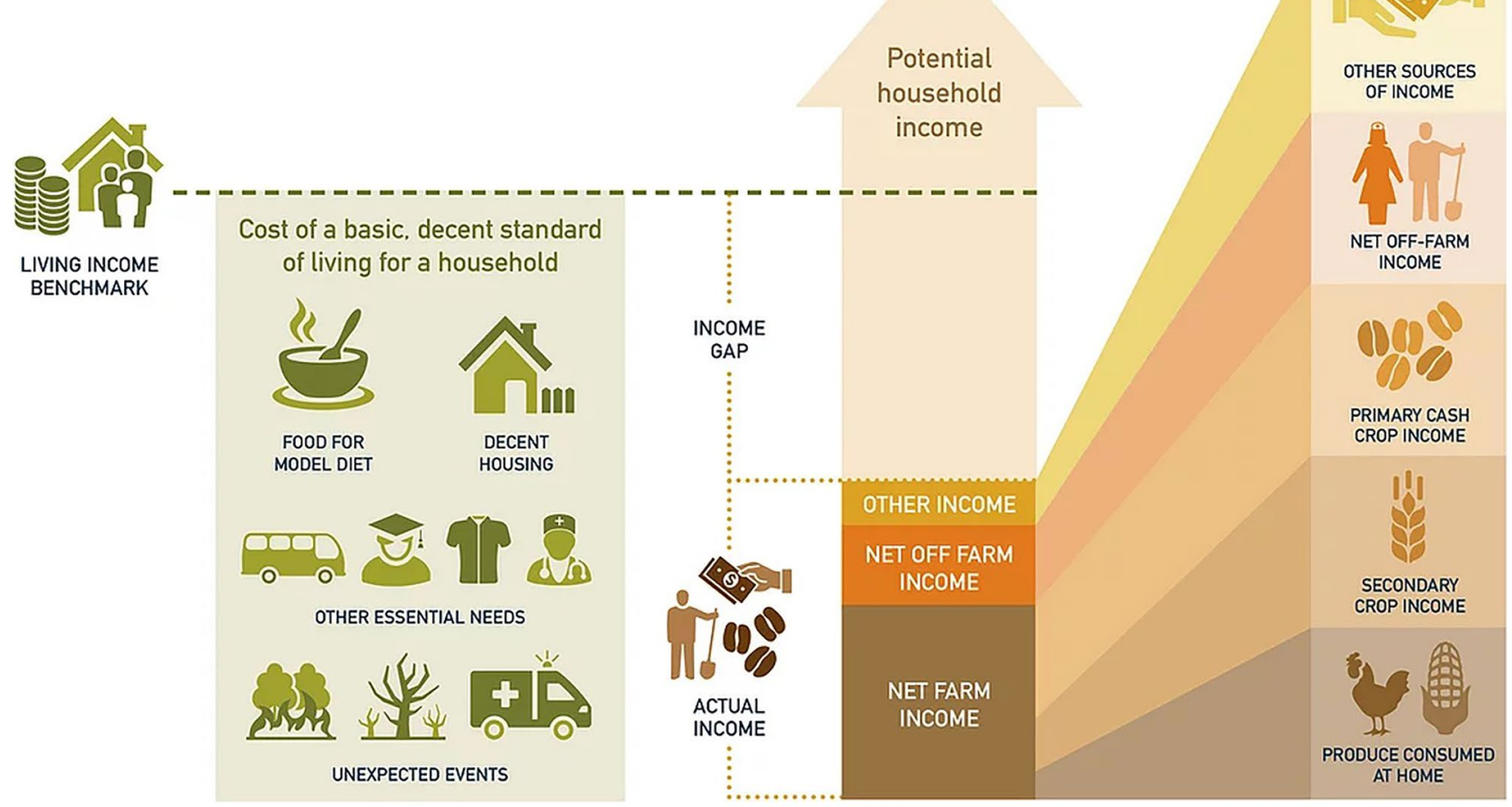

Fig. 7 Schematic representation of the living income concept (Tyszler et al., 2020) 


\subsection{Living wage gap for banana plantation workers in Costa Rica}

The living wage benchmark in Costa Rica for a family of four members with 1.4 workers was established at US\$ 731 per month (or US\$ 6.09 per capita per day) (Global Living Wage, 2019). Given the employment status of banana workers in Costa Rica, it is important to consider the extent to which certification schemes applied to the plantations - primarily related to environmental improvements - directly benefit individual workers from a socio-economic perspective. For instance, cooperatives receive US\$ 1 extra for each $18 \mathrm{~kg}$ box sold under the 'Fairtrade' label (Ostertag et al., 2014) and only modest benefits to workers' livelihood as a result of the application of certification schemes in banana plantations have been reported (van Rijn et al., 2020). Nonetheless, based on a preliminary survey, the Sustainable Trade Initiative (IDH) has estimated that over $50 \%$ of banana workers in Costa Rica receive wages above living wage benchmarks, while the remaining workers receive wages that are $10 \%$ lower than the living wage benchmark (IDH, 2020). Moreover, Robinson (2010) reported that wages in Costa Rica for banana workers are amongst the highest in comparison to other countries in LAC. The extent to which certification schemes were responsible for addressing the living wage gap is unclear, as the benefits of certification schemes in banana plantations in Costa Rica are commonly correlated with environmental improvements and reduction in pesticide usage (Willer et al., 2019). The banana sector in Costa Rica may not provide the full picture in LAC. In fact, migrants from other countries in LAC seek work in the banana sector in Costa Rica and they often face many challenges, such as employment insecurity, minimal barging power to improve working conditions and poor access to accommodation and healthcare (FAO, 2021).

\subsection{Living income gap for cocoa smallholder farmers in Côte d'Ivoire}

The living income benchmark in Côte d'Ivoire for a family of six members was established at US\$ 454 per month (or US\$ 2.52 per capita per day) (Living Income, 2018). In reality, the average income for cocoa smallholders in Côte d'Ivoire has been estimated to be US\$ 0.78 per capita per day, leaving $91 \%$ of smallholders incapable of achieving a living income (Rusman et al., 2018). Premiums paid by certification schemes could potentially alleviate the income gap of cocoa smallholders. However, in the case of cocoa in Côte d'Ivoire, Schweisguth (2015) reported that the income of some certified cocoa smallholders was equal or even lower when compared to non-certified smallholders. The average premium paid by 'UTZ - Rainforest Alliance' to cocoa smallholders in 2018 was US\$ 97.9 per t (UTZ, 2018). Considering a smallholder household producing four $t$ of cocoa per year, with a typical family size of six members, this would result in a mere addition of US\$ 0.18 per capita per day to household income, which is certainly insufficient to close the income gap. In 2020, after the merger of 'Rainforest Alliance' and 'UTZ', the prevailing label of 'Rainforest Alliance' has updated its premium policies by establishing two payment requirements for commodity buyers: Sustainability Differential and Sustainability Investments. Allegedly aware of the challenges faced by cocoa farmers, 'Rainforest Alliance' has set the Sustainability Differential at a minimum of USD 70 per $t$ that needs to reach the farm in full. On the other hand, the Sustainability Investment premium needs to be paid based on an investment plan developed during audits. Both requirements will apply from 2022 (Rainforest Alliance, 2021). As seen, the minimum premium established now is lower than the average value reported in 2018, and even lower than the amount needed to close the income gap among Ivorian cocoa smallholders. 'Fairtrade International' pays premiums of US\$ 240 per t of cocoa beans on top of a "Fairtrade Minimum Price" of US\$2400 per t of cocoa beans (Fairtrade International, 2020a). Therefore, from a socioeconomic perspective, the 'Fairtrade' logo assumes a more reasonable approach in closing income gaps for cocoa smallholders. Overall results tend to be beneficial when it comes to a higher profitability obtained by smallholders (FAO, 2014; Fenger et al., 2017; Foundjem-Tita et al., 2016). 'Fairtrade International' itself recognizes that there is room for improvement (da Silva, 2020). In its survey amongst its West African certified growers published in 2018 , it is indicated that $42 \%$ of cocoa farmers are above the extreme poverty line (US\$ 1.90 per capita/per day), however only $12 \%$ of them can realize a living income. Even though the demand for certified cocoa is growing, it still occupies a minor share of global cocoa trade (Nieburg, 2018). Moreover, 'Fairtrade' holds the smallest share compared to other certification schemes (Willer et al., 2019). 'Fairtrade' is, therefore, still a niche market. The possibilities and opportunities to grow are directly related to consumers' level of awareness, their understanding of the 'Fairtrade' principles and their willingness to pay more, which remains low in some markets (Gomersall \& Wang, 2011), as well as to producers' willingness to get certified. Meanwhile, the earliermentioned Cocoa Barometer 2020 refers to attempts to raise prices in order to realize living incomes for cocoa producers in Côte d'Ivoire. However, the authors of the Cocoa Barometer 2020 notice underestimations of cost of living, errors in land and production measurement, and inability of growers to raise productivity due to restrictions on crop stand rejuvenation.

\subsection{Living wage/income gaps and food security}

How does living wage/income relate to food security? To look at this relationship, we calculated the percentage of the income that is allocated to food expenditure. For Costa Rica, food expenditure has been estimated at US\$ 2.98 per 
capita per day (or US\$2.87 per capita per day if the widespread public program for provision of food at schools is considered, which reduces the domestic costs of meals at home) (Voorend et al., 2017). Comparing this number with the estimations provided by IDH on the current state of the living wage gap, banana workers in Costa Rica would be expected to allocate about $50 \%$ of their wages to food expenditure, which does not indicate a risk for food security. For Côte d'Ivoire, food expenditure has been estimated at US\$ 1.24 per capita per day (Knoema, 2018). Considering that the average income of Ivorian cocoa smallholders is US\$ 0.78 per capita per day, there is a clear risk for food security. In fact, the figures used within the living income benchmark established for Côte d'Ivoire point to the need of US\$ 1.20 per capita per day to sustain a decent nutrition intake (Tyszler et al., 2019).

\subsection{Can certification schemes do the job they are expected to?}

Certification schemes, in general, are claimed to be an attractive way for farmers to achieve better livelihood conditions (Cargill, 2019; UTZ, 2019). However, due to the high costs of being certified there are still concerns about the potential risk that certification schemes actually increase inequalities among growers or exclude those that are incapable of affording the costs of certification (Drigo et al., 2009; Pinto et al., 2014). Aligned to that, the exclusion of smallholder farmers was named as one of the constraints for the continued expansion of markets for certified commodities (Iseal Alliance, 2011). Therefore, it is clear that smallholders need external governance tools to simultaneously promote more sustainable practices in cocoa cultivation and achieve a better livelihood.

Nearly all certification schemes include environmental performance criteria in order to reduce the environmental impact from farming. Authors critique these criteria because they are often designed from a Western consumer perspective rather than from a local producer perspective (Hatanaka, 2010). As a consequence, smallholders have to follow guidelines that do not fit their everyday reality and may even complicate their work without adequate compensation. This means that these smallholders may consider certification schemes and their requirements more as a means to access international markets than as a way to improve their livelihood and secure their environment.

Private voluntary certification schemes are often seen as opposed to mandatory governmental regulation and therefore as competing ways to address critical issues of sustainability. Certification schemes are considered more flexible, but they lack the authority and legitimacy that governmental regulations possess (Oosterveer, 2015). Governmental regulations may be mandatory and supported by a country's decision-making procedures although they are often slow in being introduced, depend on the presence of sufficient political will and their effectiveness depends on the often very limited capacity for implementation and monitoring. However, rather than being forced to choose between these two options it may be more promising to combine both. This paper showed how private initiatives may serve as the initiator of important changes but that the involvement of government authorities is necessary to provide important support through training and regulatory frameworks, such as with the environmental regulations in Costa Rica.

In the case of cocoa, as a common rule, if you are a certified smallholder, you are organized in a farmers' group or cooperative. This is because individual smallholders do not possess the financial resources, technical capability and inputs to certify themselves individually. We already mentioned that the price and efforts to be certified constitute one of the biggest barriers for certification schemes to spread further among farmers. Certification standards require an initial investment from farmers to upgrade their farming conditions towards more socially or environmentally friendly practices. On the other hand, smaller and poorer smallholders who are not integrated into cooperatives end up being further marginalized. Most development interventions realized within cocoa communities happen within the boundaries of certified cooperatives (da Silva, 2020). In general, farmers who are both certified and a member of a cooperative enjoy benefits that help them have better access to market information, to inputs, and are therefore one step ahead on the living income ladder. As a result, non-organized farmers are not only excluded from certified value chains but often also from external aid.

In the case of bananas, despite limited economic impact on primary wages, certification schemes may still provide other social benefits to banana workers. For instance, van Rijn et al. (2020) investigated banana plantations certified by 'Fairtrade International' in the Dominican Republic and reported that the certification scheme had some relevant positive effects on labour conditions, particularly by delivering in-kind benefits, offering a sense of job security and enabling private savings. According to these authors, 'Fairtrade International' also seems to have a positive effect on the 'voice' of wage workers. In this context, positive outcomes of certification schemes may not be reflected in better wages or basic labour conditions, which may in fact fall under the direct control of national and international law. Instead, the positive outcomes of certification schemes should also be assessed in terms of social benefits (e.g., access to and satisfaction with sanitation and healthcare), and especially in terms of voice-related benefits (van Rijn et al., 2020). The current (economic) focus on living wages in the sector tends to overlook these less tangible, but equally important (social) benefits of certification schemes (van Rijn et al., 2020). 
It is important to note that attributing any major improvement in farmers' livelihood solely to certification schemes is difficult since other drivers of change that promote overall socio-economic improvements (i.e., policies and regulations) may simultaneously play a role. Furthermore, as pointed out by van Rijn et al. (2020), a simple comparison between certified versus non-certified farms/individuals is unlikely to provide the complete answer. For instance, if differences between certified and non-certified farms/individuals are not observed, this may be because certified farms/ individuals could have been in a worse situation to start with, but have in fact improved. Moreover, as compliance with other national/international regulations in the production of export commodities becomes more generalised, differences between certified and non-certified plantations tend to become smaller over time.

\section{Conclusions}

We have argued in this paper that there is added value in taking a closer look at export commodities by combining analysis of the food system with the analysis of power imbalances in the global export sector. Export commodities, such as banana and cocoa, are characterized by global value chain rules and long distances between producers and consumers. These products are part of global food systems and part of people's diets across the world. Many drivers affect the position of such crops and commodities in food systems. These can be more complex drivers such as climate change, population growth, urbanisation, and the spreading of a plant disease, whereas others can be influenced more directly, such as trade policies, pricing, boosting information technology, or influencing consumer behaviour. For banana and cocoa in particular, the environmental and socio-economic vulnerability of the systems where these commodities are produced gained increased attention in the consumer countries, and led to the introduction of certification schemes, which can be seen as a specific export croprelated driver. To reduce the vulnerability, the banana sector predominantly focussed on the health of plantation workers and on environmental pollution, whereas the cocoa sector predominantly focussed on the market position of smallholders and on relegated workers (e.g., women, children). We concluded that certification schemes have some positive impacts on the livelihoods of banana plantation workers in Costa Rica and cocoa smallholders in Côte d'Ivoire, but that significant gaps remain.. In particular, to effectively improve the livelihood of smallholder cocoa growers in Côte d'Ivoire, much still remains to be done. In this study, we focused on Costa Rica and Côte d'Ivoire, however, it is important to note that the picture might be different for other banana and cocoa export countries.
The presented analysis has also generated conclusions on using a food systems perspective when analysing global commodity chains. First, using this perspective illustrated how the drivers and actors in the food system influence the outcomes of the system; in this case the gaps in living wage/income. With respect to global export commodities, such as banana and cocoa, it is especially important to better understand how the food system drivers are subject to power relations. Second, the food system approach showed that an integrated approach can help create synergies among different food system outcomes. In our case, avenues are made visible that address improved environmental sustainability and resilience as well as socio-economic well-being of plantation workers and smallholders simultaneously. Third, certification schemes remain a popular strategy to improve the livelihoods of smallholder farmers and plantation workers. However, as we showed in the overview, their effects may be limited, depending on the specific approach of the scheme and the local conditions. And, in particular, a certification scheme should not be considered a singular, independent improvement strategy but an intervention in an already existing food system and therefore needs to be supplemented with additional interventions to sustainably increase productivity and diversify income sources.

Acknowledgments This article is derived from chapters 4 and 9 of the Rural Development Report (IFAD, 2021). All authors contributed to the study conception and design. Material preparation, data collection and analysis were performed by Carlos F.B.V. Alho and Amanda F. da Silva. The first draft of the manuscript was written by Carlos F.B.V. Alho and all authors commented on previous versions of the manuscript. All authors read and approved the final manuscript.

Funding This study was supported by the International Fund for Agricultural Development (IFAD)

\section{Declarations}

Ethics approval Not applicable.

Consent to participate Not applicable.

Consent for publication Not applicable.

Conflicts of interest There are no conflicts of interest.

Open Access This article is licensed under a Creative Commons Attribution 4.0 International License, which permits use, sharing, adaptation, distribution and reproduction in any medium or format, as long as you give appropriate credit to the original author(s) and the source, provide a link to the Creative Commons licence, and indicate if changes were made. The images or other third party material in this article are included in the article's Creative Commons licence, unless indicated otherwise in a credit line to the material. If material is not included in the article's Creative Commons licence and your intended use is not permitted by statutory regulation or exceeds the permitted use, you will 
need to obtain permission directly from the copyright holder. To view a copy of this licence, visit http://creativecommons.org/licenses/by/4.0/.

\section{References}

Aboa, A. (2021). Ivory Coast lost 47,000 hectares of forest to cocoa production in 2020, environmental group says. Reuters. Retrieved 18 June 2021, from https://www.reuters.com/article/ uk-cocoa-ivorycoast-deforestation-idUSKBN2AJ0T6

Agritrade. (2013). Executive brief update 2013: Cocoa sector. CTA. Retrieved June 18, 2021, from https://agritrade.cta.int/Agriculture/ Commodities/Cocoa/Executive-Brief-Update-2013-Cocoa-sector. html

Argout, X., Salse, J., Aury, J. M., Guiltinan, M. J., Droc, G., Gouzy, J., Allegre, M., et al. (2011). The genome of Theobroma cacao. Nature Genetics, 43(2), 101-108. https://doi.org/10.1038/ng. 736

Arias-Andrés, M., Rämö, R., Mena Torres, F., Ugalde, R., Grandas, L., Ruepert, C., et al. (2018). Lower tier toxicity risk assessment of agriculture pesticides detected on the Río Madre de Dios watershed, Costa Rica. Environmental Science and Pollution Research, 25(14), 13312-13321. https://doi.org/10.1007/ s11356-016-7875-7

Bellamy, A. S. (2013). Banana production systems: Identification of alternative systems for more sustainable production. Ambio, 42(3), 334-343. https://doi.org/10.1007/s13280-012-0341-y

Bellamy, A. S., Svensson, O., van den Brink, P. J., \& Tedengren, M. (2016). What is in a label? Rainforest-Alliance certified banana production versus non-certified conventional banana production. Global Ecology and Conservation, 7, 39-48. https://doi. org/10.1016/j.gecco.2016.05.002

Béné, C., Prager, S. D., Achicanoy, H. A. E., Toro, P. A., Lamotte, L., Cedrez, C. B., \& Mapes, B. R. (2019). Understanding food systems drivers: A critical review of the literature. Global Food Security, 23(April), 149-159. https://doi.org/10.1016/j. gfs.2019.04.009

Boeckx, P., Bauters, M., \& Dewettinck, K. (2020). Poverty and climate change challenges for sustainable intensification of cocoa systems. Current Opinion in Environmental Sustainability, 47, 106-111. https://doi.org/10.1016/j.cosust.2020.10.012

Boström, M., Micheletti, M., \& Oosterveer, P. (2019). The Oxford Handbook of Political Consumerism. Oxford University Press. https://doi.org/10.1093/oxfordhb/9780190629038.001.0001

Boylan, S., Sainsbury, E., Thow, A. M., Degeling, C., Craven, L., Stellmach, D., Gill, T. P., \& Zhang, Y. (2019). A healthy, sustainable and safe food system: Examining the perceptions and role of the Australian policy actor using a Delphi survey. Public Health Nutrition, 22(16), 2921-2930. https://doi.org/10. 1017/S136898001900185X

Bush, S. R., Belton, B., Hall, D., Vandergeest, P., Murray, F. J., Ponte, S., Oosterveer, P., et al. (2013). Certify sustainable aquaculture? Science, 341(6150), 1067-1068. https://doi.org/ $10.1126 /$ science. 1237314

Bymolt, R., Laven, A., \& Tyszler, M. (2018). Demystifying the cocoa sector in Ghana and Côte d'Ivoire. KIT. Retrieved 18 June 2021, from https://www.kit.nl/wp-content/uploads/2020/ 05/Demystifying-complete-file.pdf

Cargill. (2019). Cocoa certifications. Cargill. Retrieved 18 June 2021, from https://www.cargill.com/sustainability/cocoa/ cocoa-certification

CBI. (2019). What is the demand for cocoa on the European market? CBI. Retrieved 18 June 2021, from https://www.cbi.eu/marketinformation/cocoa/trade-statistics
Chiquita. (2019). Sustainability Report. Chiquita. Retrieved 18 June 2021, from https://chiquitabrands.com/wp-content/uploads/ 2020/01/Sustainability-Report_2019_Chiquita-1.pdf

Corbana. (2021). Banano de Costa Rica. Corbana. Retrieved 18 June 2021, from https://www.corbana.co.cr/banano-de-costa-rica/

Crane, A., Matten, D., \& Spence, L. (2008). Corporate Social Responsibility: Readings and Cases in Global Context. Routledge. https://doi.org/10.4324/9780429294273-2

Czischke, D., Gruis, V., \& Mullins, D. (2012). Conceptualising social enterprise in housing organisations. Housing Studies, 27(4), 418-437. https://doi.org/10.1080/02673037.2012.677017

D’hont, A., Denoeud, F., Aury, J. M., Baurens, C. F., Carreel, F., Garsmeur, O., Noel., B., et al. (2012). The banana (Musa acuminata) genome and the evolution of monocotyledonous plants. Nature, 488(7410), 213-217. https://doi.org/10.1038/nature11241

da Silva, A. (2020). Mechanisms for shared responsibility in the cocoa global value chain: the traders' perspective on living income. Master's thesis, Wageningen University \& Research.

Dale, J., James, A., Paul, J. Y., Khanna, H., Smith, M., Peraza-Echeverria, S., Garcia-Bastidas, F., Kema, G., et al. (2017). Transgenic Cavendish bananas with resistance to Fusarium wilt tropical race 4. Nature Communications, 8(1), 1-8. https://doi.org/10.1038/s41467-017-01670-6

Davison, K., Berry, N. M., Misan, G., Coates, A. M., Buckley, J. D., \& Howe, P. (2010). Dose-related effects of flavanol-rich cocoa on blood pressure. Journal of Human Hypertension, 24, 568-576. https://doi.org/10.1038/jhh.2009.105

de Beule, H., Jassogne, L, van Asten P. (2014). Cocoa : Driver of deforestation in the Democratic Republic of Congo? CCAFS CGIAR. Retrieved June 18, 2021, from https://ccafs.cgiar.org/resources/ publications/cocoa-driver-deforestation-democratic-republic-congo

Dormon, E. N. A., Van Huis, A., Leeuwis, C., Obeng-Ofori, D., \& SakyiDawson, O. (2004). Causes of low productivity of cocoa in Ghana: farmers' perspectives and insights from research and the socio-political establishment. NJAS: Wageningen Journal of Life Sciences, 52(3-4), 237-259. https://doi.org/10.1016/S1573-5214(04)80016-2

Drigo, I. G., Piketty, M. G., \& Abramovay, R. (2009). Certification of community-based forest enterprises (CFEs): Limits of the Brazilian experiences. Ethique Economique, 6(2), 1-20.

Duku, C., Alho, C., Leemans, R. and Groot, A. (2021). Climate change and food systems. Background paper for the Rural Development Report. IFAD. Rome: Italy.

Echeverría-Sáenz, S., Mena, F., Arias-Andrés, M., Vargas, S., Ruepert, C., Van den Brink, P. J., Castillo, L. E., \& Gunnarsson, J. S. (2018). In situ toxicity and ecological risk assessment of agro-pesticide runoff in the Madre de Dios River in Costa Rica. Environmental Science and Pollution Research, 25(14), 13270-13282. https://doi. org/10.1007/s11356-016-7817-4

Fairtrade International. (2020a). Fairtrade and Minumun Price and Price Information. Fairtrade International. Retrieved 18 June 2021, from https://www.fairtrade.net/standard/minimum-price-info

Fairtrade International. (2020b). How FairTrade works. Fairtrade International. Retrieved 18 June 2021, from https://www.fairtrade.net/ about/how-fairtrade-works

FAO. (2014). Impact of international voluntary standards on smallholder market participation in developing countries - A review of the literature. FAO. Retrieved 18 June 2021, from https://www. fao.org/3/i3682e/i3682e.pdf

FAO. (2019). Banana Fusarium Wilt Tropical Race 4: A mounting threat to the global banana markets? FAO. Retrieved 18 June 2021, from https://www.fao.org/3/ca6911en/CA6911EN_TR4EN.pdf

FAO. (2020). FAOSTAT statistical database. FAO. Retrieved 18 June 2021, from https://www.fao.org/faostat/en/

FAO. (2021). Migrant workers in the banana industry. FAO. Retrieved 18 June 2021, from http://www.fao.org/world-banana-forum/ projects/good-practices/migrant-workers/en/ 
Fenger, N. A., Bosselmann, A. S., Asare, R., \& De Neergaard, A. (2017). The impact of certification on the natural and financial capitals of Ghanaian cocoa farmers. Agroecology and Sustainable Food Systems, 41(2), 143-166. https://doi.org/10.1080/ 21683565.2016.1258606

Fold, N., \& Neilson, J. (2016). Sustaining Supplies in SmallholderDominated Value Chains. In M. P. Squicciarini \& J. Swinnen The Economics of Chocolate (pp. 195-212). Oxford University Press. https://doi.org/10.1093/acprof:oso/9780198726449.003.0011

Fonsah, E. G., \& Chidebelu, A. S. N. D. (2011). Economics of Banana Production and Marketing in the Tropics: A Case Study of Cameroon. LANGAA RPCIG

Food Navigator. (2019). Barry Callebaut eyes India's fast-growing chocolate industry with new factory. Food Navigator. Retrieved 18 June 2021, from https://www.foodnavigator-asia.com/Article/ 2019/08/05/Barry-Callebaut-eyes-India-s-fast-growing-chocolateindustry-with-new-factory

Foundjem-Tita, D., Donovan, J., Stoian, D., \& Degrande, A. (2016). Baseline for Assessing the Impact of Fairtrade Certification on Cocoa Farmers and Cooperatives in Ghana Divine. World Agroforestry Centre. Retrieved 18 June 2021, from http://apps.worldagroforestry. org/downloads/Publications/PDFS/RP17353.pdf

Fountain, A., \& Hütz-Adams, F. (2020). The Cocoa Barometer 2020. Voice Network. Retrieved 18 June 2021, from https://www. voicenetwork.eu/wp-content/uploads/2021/03/2020-CocoaBarometer-EN.pdf

Fournier, M. L., Echeverría-Sáenz, S., Mena, F., Arias-Andrés, M., de la Cruz, E., \& Ruepert, C. (2018). Risk assessment of agriculture impact on the Frío River watershed and Caño Negro Ramsar wetland, Costa Rica. Environmental Science and Pollution Research, 25(14), 13347-13359. https://doi.org/10.1007/ s11356-016-8353-y

Franzen, M., \& Mulder, M. B. (2007). Ecological, economic and social perspectives on cocoa production worldwide. Biodiversity and Conservation, 16(13), 3835-3849. https://doi.org/10.1007/ s10531-007-9183-5

Garcia-Bastidas, F., Quintero-Vargas, C., Ayala-Vasquez, M., Seidl, M., Schermer, T., Santos-Paiva, M., Noguera, A. M., et al. (2019). First report of Fusarium wilt Tropical Race 4 in Cavendish bananas caused by Fusarium odoratissimum in Colombia. Plant Disease, 104(3), 994-994.

Gereffi, G., \& Fernandez-Stark, K. (2018). Global Value Chain Analysis: A Primer (Second Edition). In G. Gereffi, Global Value Chains and Development: Redefining the Contours of 21 st Century Capitalism (Development Trajectories in Global Value Chains, (pp. 305-342). Cambridge University Press. https://doi. org/10.1017/9781108559423.012

Getz, C., \& Shreck, A. (2006). What organic and Fair Trade labels do not tell us: Towards a place-based understanding of certification. International Journal of Consumer Studies, 30(5), 490-501. https://doi.org/10.1111/j.1470-6431.2006.00533.x

Glasbergen, P. (2018). Smallholders do not Eat Certificates. Ecological Economics, 147, 243-252. https://doi.org/10.1016/j.ecolecon. 2018.01.023

Global Living Wage. (2018). What is a living wage? Global Living Wage. Retrieved 18 June 2021, from https://globallivingwage.org/

Global Living Wage. (2019). Living Wage Benchmarks. Global Living Wage. Retrieved 18 June 2021, from https://www.globallivingwage. org/resource-library/?fwp_resource_type=livingwage

Global Value Chains. (2017). Concept \& Tools. Global Value Chains. Retrieved 18 June 2021, from https://globalvaluechains.org/ concept-tools

Gomersall, K., \& Wang, M. Y. (2011). Expansion of Fairtrade products in Chinese market. Journal of Sustainable Development, 5(1), 23. https://doi.org/10.5539/jsd.v5n1p23
Hatanaka, M. (2010). Certification, partnership, and morality in an organic shrimp network: Rethinking transnational alternative agrifood networks. World Development, 38(5), 706-716. https:// doi.org/10.1016/j.worlddev.2009.11.001

HLPE. (2017). Nutrition and food systems. HLPE. Retrieved 18 June 2021, from http://www.fao.org/3/a-i7846e.pdf

Howard, P. H. (2016). Concentration and Power in The Food System: Who Controls What We Eat? Bloomsbury Publishing. https:// doi.org/10.7202/1038484ar

ICCO. (2016). ICCO Daily Prices of Cocoa Beans. ICCO. Retrieved 18 June 2021, from https://www.icco.org/statistics/

IDH. (2020). Bananas in Costa Rica and Belize. IDH. Retrieved 18 June 2021, from https://www.idhsustainabletrade.com/publication/ bananas-in-costa-rica-and-belize/

IFAD. (2021). Transforming food systems for rural prosperity. Rural Development Report. IFAD. Rome: Italy.

Speranza, C. I. (2013). Buffer capacity: Capturing a dimension of resilience to climate change in African smallholder agriculture. Regional Environmental Change, 13(3), 521-535. https://doi.org/ 10.1007/s10113-012-0391-5

Ingram, J. (2011). A food systems approach to researching food security and its interactions with global environmental change. Food Security, 3(4), 417-431. https://doi.org/10.1007/ s12571-011-0149-9

Ingram, V. (2015). The true price of chocolate? Agro Food Industry Hi-Tech, 26(1), 29-33.

Iseal Alliance. (2011). Stepwise Approaches as a Strategy for Scaling Up. Iseal Alliance. Retrieved 18 June 2021, from https://platf orm.isealalliance.org/sites/default/files/Stepwise_Approaches_ Background_Report_April2011.pdf

Jacobi, J., Schneider, M., Pillco Mariscal, M., Huber, S., Weidmann, S., Bottazzi, P., \& Rist, S. (2015). Farm resilience in organic and nonorganic cocoa farming systems in Alto Beni, Bolivia. Agroecology and Sustainable Food Systems, 39(7), 798-823. https://doi.org/10.1080/21683565.2015.1039158

Jagoret, P., Snoeck, D., Bouambi, E., Ngnogue, H. T., Nyassé, S., \& Saj, S. (2018). Rehabilitation practices that shape cocoa agroforestry systems in Central Cameroon: key management strategies for long-term exploitation. Agroforestry Systems, 92(5), 1185-1199. https://doi.org/10.1007/s10457-016-0055-4

Karangwa, P., Blomme, G., Beed, F., Niyongere, C., \& Viljoen, A. (2016). The distribution and incidence of banana Fusarium wilt in subsistence farming systems in east and central Africa. Crop Protection, 84, 132-140. https://doi.org/10.1016/j.cropro.2016. 03.003

Knoema. (2018). Côte d'Ivoire - Expenditure on food per capita. Knoema. Retrieved 18 June 2021, from https://knoema.com/ atlas/C\%C3\%B4te-dIvoire/topics/Food-Security/ExpendituresSpent-on-Food/Expenditure-on-food-per-capita

Kummu, M., Kinnunen, P., Lehikoinen, E., Porkka, M., Queiroz, C., Röös, E., Troell, M., \& Weil, C. (2020). Interplay of trade and food system resilience: Gains on supply diversity over time at the cost of trade independency. Global Food Security, 24, 100360. https://doi.org/10.1016/j.gfs.2020.100360

Lambin, E. F., Gibbs, H. K., Heilmayr, R., Carlson, K. M., Fleck, L. C., Garrett, R. D., Le Polain De Waroux, Y., et al. (2018). The role of supply-chain initiatives in reducing deforestation. Nature Climate Change, 8(2), 109-116. https://doi.org/10.1038/s41558-017-0061-1

Laven, A., Buunk, E., \& Ammerlaan, T. (2016). Appendix A - Determination of Cocoa Prices in Cameroon, Nigeria, Ghana, Côte d'Ivoire and Indonesia. SEO Amsterdam. Retrieved 18 June 2021, from https://www.parlementairemonitor.nl/9353000/1/j4nvgs5kjg27kof_ j9vvij5epmj1ey0/vkbdhosa52zz/f=/blg797984.pdf

Lee, D. (2009). Understanding aquaculture certification. Revista Colombiana de Ciencias Pecuarias, 22(3). 
Leeuwis, C., Boogaard, B.K. and Atta-Krah, K. (2021). How Food Systems Change (or Not): Governance Implications for System Transformation Processes. Background paper for the Rural Development Report. IFAD. Rome: Italy

Liu, P., Andersen, M., \& Pazderka, C. (2004). Voluntary standards and certification for environmentally and socially responsible agricultural production and trade. FAO. Retrieved 18 June 2021, from https://www.fao.org/3/y5763t/y5763t.pdf

Living Income. (2018). Côte d'Ivoire: Validating the Living Income Benchmark for cocoa growing regions. Living Income. Retrieved 18 June 2021, from https://www.living-income.com/single-post/ 2018/09/26/c\%C3\%B4te-d-ivoire-validating-the-living-incomebenchmark-for-cocoa-growing-regions

Living Income. (2019). The Concept. Living Income. Retrieved 18 June 2021, from https://www.living-income.com/the-concept

Makate, C., Wang, R., Makate, M., \& Mango, N. (2016). Crop diversification and livelihoods of smallholder farmers in Zimbabwe: Adaptive management for environmental change. SpringerPlus, 5(1). https://doi.org/10.1186/s40064-016-2802-4

Malan, B. B. (2013). Volatility and stabilization of the price of coffee and cocoa in Côte d'Ivoire. Agricultural Economics (Czech Republic), 59(7), 333-340.

Maloni, M. J., \& Brown, M. E. (2006). Corporate social responsibility in the supply chain: An application in the food industry. Journal of Business Ethics, 68(1), 35-52. https://doi.org/10.1007/ s10551-006-9038-0

Marquardt, S. (2002). Pesticides, Parakeets, and Unions in the Costa Rican Banana Industry, 1938-1962. Latin American Research Review, 37(2), 3-36.

Maskarinec, G., Jacobs, S., Shvetsov, Y., Boushey, C. J., Setiawan, V. W., Kolonel, L. N., et al. (2019). Intake of cocoa products and risk of type-2 diabetes: the multiethnic cohort. European Journal of Clinical Nutrition, 73, 671-678. https://doi.org/10.1038/ s41430-018-0188-9

Mendez, A., Castillo, L. E., Ruepert, C., Hungerbuehler, K., \& Ng, C. A. (2018). Tracking pesticide fate in conventional banana cultivation in Costa Rica: A disconnect between protecting ecosystems and consumer health. Science of the Total Environment, 613-614, 1250-1262. https://doi.org/10.1016/j.scitotenv.2017.09.172

Mieu, B. (2020). Ghana and Côte d'Ivoire taste success in raising price of cocoa. The African Report. Retrieved 18 June 2021, from https://www.theafricareport.com/40945/ghana-and-cote-divoi re-taste-success-in-raising-price-of-cocoa/

Molenaar, J. W., \& Short, D. (2018). Strategies to close the living income gap of smallholder farmers: The cases of cocoa in Côte d'Ivoire and rubber in Indonesia. Aidenenvironment. Retrieved 18 June 2021, from https://docs.wixstatic.com/ugd/0c5ab3 bf337bc0c1a746c990ba003c8f5f9325.pdf

Nieburg, O. (2018). What does "going beyond certification" in cocoa sustainability really mean? Confectionary News. Retrieved 18 June 2021, from https://www.confectionerynews.com/Article/ 2018/02/20/What-does-going-beyond-certification-in-cocoasustainability-mean

Nkurunziza, J. D., Tsowou, K., \& Cazzaniga, S. (2017). Commodity dependence and human development. African Development Review, 29(S1), 27-41. https://doi.org/10.1111/1467-8268.12231

Odorico, P. D., Carr, J. A., Laio, F., Ridolfi, L., \& Vandoni, S. (2014). Feeding humanity through global food trade. Earth's Future, 2, 458-469. https://doi.org/10.1002/2014EF000250.Abstract

Oosterveer, P. (2015). Authority and legitimacy in governing global food chains. In T. Havinga, The Changing Landscape of Food Governance: Public and Private Encounters (pp. 117-133). Edward Elgar Publishing Ltd. https://doi.org/10.4337/9781784715410.00017

Ostertag, C., Sandoval, O., Barona, J., \& Mancilla, C. (2014). An Evaluation of Fairtrade Impact on Smallholders and Workers in the Banana Sector in northern Colombia. CODER.
Retrieved June 18, 2021, from https://files.fairtrade.net/publi cations/2014_BananaColombiaImpact.pdf

Perrier, X., De Langhe, E., Donohue, M., Lentfer, C., Vrydaghs, L., Bakry, F., Carreel, F., et al. (2011). Multidisciplinary perspectives on (Musa spp.) domestication. Proceedings of the National Academy of Sciences of the United States of America, 108(28), 11311-11318. https://doi.org/10.1073/pnas.1102001108

Pinto, L. F. G., Gardner, T., McDermott, C. L., \& Ayub, K. O. L. (2014). Group certification supports an increase in the diversity of sustainable agriculture network-rainforest alliance certified coffee producers in Brazil. Ecological Economics, 107, 59-64. https://doi.org/10.1016/j.ecolecon.2014.08.006

Ponte, S., \& Gibbon, P. (2005). Quality standards, conventions and the governance of global value chains. Economy and Society, 34(1), 1-31. https://doi.org/10.1080/0308514042000329315

Poore, J., \& Nemecek, T. (2018). Reducing food's environmental impacts through producers and consumers. Science, 360(6392), 987-992. https://doi.org/10.1126/science.aaq0216

Rainforest Alliance. (2021). Cocoa: The Sustainability Differential. Rainforest Alliance. Retrieved June 18, 2021, from https:// www.rainforest-alliance.org/business/responsible-sourcing/ supply-chain-certification/cocoa-sustainability-differential/

Rämö, R. A., van den Brink, P. J., Ruepert, C., Castillo, L. E., \& Gunnarsson, J. S. (2018). Environmental risk assessment of pesticides in the River Madre de Dios, Costa Rica using PERPEST, SSD, and msPAF models. Environmental Science and Pollution Research, 25(14), 13254-13269. https://doi.org/10.1007/s11356-016-7375-9

Robinson, P. K. (2010). Responsible retailing: The practice of CSR in banana plantations in Costa Rica. Journal of Business Ethics, 91(SUPPL 2), 279-289. https://doi.org/10.1007/ s10551-010-0619-6

Ruf, F., Schroth, G., \& Doffangui, K. (2015). Climate change, cocoa migrations and deforestation in West Africa: What does the past tell us about the future? Sustainability Science, 10(1), 101-111. https://doi.org/10.1007/s11625-014-0282-4

Rusman, A., Toorop, R. de A., de Broer, J., \& Ruiz, A. de G. (2018). The household income of cocoa farmers in Côte d'Ivoire and strategies for improvement. True Price. Retrieved 18 June 2021, from https://files.fairtrade.net/publications/2018_ FairtradeCocoaFarmerIncomeCDI.pdf

Schroth, G., Läderach, P., Martinez-Valle, A. I., Bunn, C., \& Jassogne, L. (2016). Vulnerability to climate change of cocoa in West Africa: Patterns, opportunities and limits to adaptation. Science of the Total Environment, 556, 231-241. https://doi.org/10. 1016/j.scitotenv.2016.03.024

Sonwa, D. J., Weise, S. F., Schroth, G., Janssens, M. J. J., \& Shapiro, Howard-Yana. (2014). Plant diversity management in cocoa agroforestry systems in West and Central Africa-effects of markets and household needs. Agroforestry Systems, 88(6), 1021-1034. https://doi.org/10.1007/s10457-014-9714-5

Schweisguth, M. A. (2015). Evaluating the Effects of Certification on Smallholders' Net Incomes, with a Focus on Cacao Farmers in Cooperatives in Côte d'Ivoire. Master's thesis. University of Carlifornia.

SCIJ. (2021). Reforma Crea la Corporación Bananera Nacional (CORBANA). SCIJ. Retrieved 18 June 2021, from https://www.pgrweb. go.cr/scij/Busqueda/Normativa/Normas/nrm_texto_completo. aspx ?param $1=$ NRTC $\&$ Valor $1=1 \&$ nValor $2=86458 \&$ nValor $3=$ $112164 \&$ param $2=1 \&$ strTipM $=$ TC $\& 1$ Resultado $=2 \&$ strSim $=$ simp

Scott, G. J. (2021). A review of root, tuber and banana crops in developing countries: past, present and future. International Journal of Food Science and Technology, 56(3), 1093-1114. https://doi. org/10.1111/ijfs. 14778

StatInvestor. (2021). Global chocolate consumption per capita in 2017, by country. StatInvestor. Retrieved 18 June 2021, from https:// statinvestor.com/data/28384/leading-chocolate-consumingcountries-worldwide/ 
Terazono, E. (2014). Welcome to the world of Big Chocolate. Financial Times. Retrieved June 18, 2021, from https://www.ft.com/ content/80e196cc-8538-11e4-ab4e-00144feabdc0

Thorlakson, T. (2018). A move beyond sustainability certification: The evolution of the chocolate industry's sustainable sourcing practices. Business Strategy and the Environment, 27(8), 1653-1665. https://doi.org/10.1002/bse.2230

Thrupp, L. A. (1991). Long-term losses from accumulation of pesticide residues: a case of persistent copper toxicity in soils of Costa Rica. Geoforum, 22(1), 1-15. https://doi.org/10.1016/ 0016-7185(91)90026-M

Tokede, O. A., Gaziano, J. M., \& Djoussé, L. (2011). Effects of cocoa products/dark chocolate on serum lipids: a meta-analysis. European Journal of Clinical Nutrition, 65, 879-886. https://doi.org/ 10.1038/ejen.2011.64

Tyszler, M., Bymolt, R., \& Laven, A. (2019). Analysis of the income gap of cocoa producing households in Côte d'Ivoire. KIT. Retrieved 18 June 2021, from https://www.kit.nl/wp-content/ uploads/2019/01/Analysis-of-the-income.pdf

Tyszler, M., Ríos, C. D. L., Serfilippi, E., Audet-Belander, G., \& Laven, A. (2020). Guidance manual on calculating and visualizing the income gap to a Living Income Benchmark. KIT. Retrieved June 18, 2021, from https://www.kit.nl/publication/ guidance-manual-on-calculating-and-visualizing-income-gapto-a-living-income-benchmark/

UNCTAD. (2019). The State of Commodity Dependence 2019. UNCTAD. Retrieved 18 June 2021, from https://unctad.org/system/ files/official-document/ditccom2019d1_en.pdf

Ureña-Saborío, H., Madrigal-Carballo, S., Sandoval, J., VegaBaudrit, J. R., \& Rodríguez-Morales, A. (2017). Encapsulation of bacterial metabolic infiltrates isolated from different Bacillus strains in chitosan nanoparticles as potential green chemistry-based biocontrol agents against Radopholus similis. Journal of Renewable Materials, 5(3-4), 290-299. https://doi. org/10.7569/JRM.2017.634119

Uribe-Leitz, E., \& Ruf, F. (2019). Cocoa Certification in West Africa: The Need for Change. In M. Schmidt, D. Giovannucci, D. Palekhov, B. Hansmann, Sustainable Global Value Chains (pp. 435461). Springer. https://doi.org/10.1007/978-3-319-14877-9_24

UTZ. (2020). Who we are. UTZ. Retrieved 18 June 2021, from https:// utz.org/who-we-are/

UTZ. (2018). UTZ Certification 2018 Cocoa Statistics. UTZ. Retrieved 18 June 2021, from https://utz.org/wp-content/uploads/2019/06/ Statistics-2018-infographics-UTZ-Cocoa-web.pdf

UTZ. (2019). Cocoa. UTZ. Retrieved 18 June 2021, from https://utz. org/what-we-offer/certification/products-we-certify/cocoa/\#

Vaast, P., Harmand, J., Rapidel, B., Jagoret, P., \& Deheuvels, O. (2016). Coffee and Cocoa Production in Agroforestry-A Climate-Smart Agriculture Model. In E. Torquebiau, Climate Change and Agriculture Worldwide, 209-224. Springer. https://doi.org/10.1007/ 978-94-017-7462-8

Vaast, P., \& Somarriba, E. (2014). Trade-offs between crop intensification and ecosystem services: the role of agroforestry in cocoa cultivation. Agroforestry Systems, 88(6), 947-956. https://doi. org/10.1007/s10457-014-9762-x

van Berkum, S., Dengerink, J., \& Ruben, R. (2018). The food systems approach: sustainable solutions for a sufficient supply of healthy food. Wageningen University \& Research. Retrieved June 18, 2021, from https://doi.org/10.18174/451505

van Berkum, S. (2021). The role of trade and policies in improving food systems outcomes. Background Paper for the Rural Development Report. IFAD. Rome: Italy

van de Ven, G. W. J., de Valença, A., Marinus, W., de Jager, I., Descheemaeker, K. K. E., Hekman, W., et al. (2020). Living income benchmarking of rural households in low-income countries. Food Security, 729-749. https://doi.org/10.1007/s12571-020-01099-8 van der Ven, H., Rothacker, C., \& Cashore, B. (2018). Do eco-labels prevent deforestation? Lessons from non-state market driven governance in the soy, palm oil, and cocoa sectors. Global Environmental Change, 52, 141-151. https://doi.org/10.1016/j. gloenvcha.2018.07.002

van Rijn, F., Fort, R., Ruben, R., Koster, T., \& Beekman, G. (2020). Does certification improve hired labour conditions and wageworker conditions at banana plantations? Agriculture and Human Values, 37(2), 353-370. https://doi.org/10.1007/s10460-019-09990-7

Varma, V., \& Bebber, D. P. (2019). Climate change impacts on banana yields around the world. Nature Climate Change, 9(10), 752-757. https://doi.org/10.1038/s41558-019-0559-9

Voora, V., Bermudez, S., \& Larrea, C. (2019). Global Market Report: Cocoa. IISD. Retrieved 18 June 2021, from https://www.iisd.org/ system/files/publications/ssi-global-market-report-cocoa.pdf

Voora, V., Larrea, C., \& Bermudez, S. (2020). Global Market Report: Bananas. IISD. Retrieved 18 June 2021, from https:// www.iisd.org/system/files/publications/ssi-global-marketreport-banana.pdf

Voorend, K., Anker, R., \& Anker, M. (2017). Living Wage Report Rural Costa Rica Limón Province (Guápiles, Guácimo, Siquirres, and Matina regions) and Heredia Province. Global Living Wage Coalition. Retrieved June 18, 2021, from https:// www.globallivingwage.org/wp-content/uploads/2019/01/LWCR-Benchmark-Report-Final-.pdf

Waarts, Y., Janssen, V., Aryeetey, R., Onduru, D., Heriyanto, D., Tin Aprillya, S., N'Guessan, A., Courbois, L. and Bakker, D. (2021). How can different types of smallholder commodity farmers be supported to achieve a living income? Background paper for the Rural Development Report. IFAD. Rome: Italy.

Waldron, A., Justicia, R., \& Smith, L. E. (2015). Making biodiversity-friendly cocoa pay: Combining yield, certification, and REDD for shade management. Ecological Applications, 25(2), 361-372. https://doi.org/10.1890/13-0313.1.sm

Wiley, J. (1998). The banana industries of Costa Rica and Dominica in a time of change. Tijdschrift Voor Economische En Sociale Geografie, 89(1), 66-81. https://doi.org/10.1111/1467-9663.00007

Willer, H., Sampson, G., Voora, V., Dang, D., \& Lernoud, J. (2019). The State of Sustainable Markets 2019 - Statistics and Emerging Trends. ITC. Retrieved 18 June 2021, from https://www.intracen. org/uploadedFiles/intracenorg/Content/Publications/Sustainabile\% 20markets\%202019\%20web.pdf

Workman, D. (2020). Bananas Exports by Country 2019. World's Top Exports. Retrieved 18 June 2021, from https://www. worldstopexports.com/bananas-exports-country/

Wunsch, N. G. (2021). Market share of the leading chocolate companies worldwide 2016. Statista. Retrieved 18 June 2021, from https://www.statista.com/statistics/629534/marketshare-leading-chocolate-companies-worldwide/

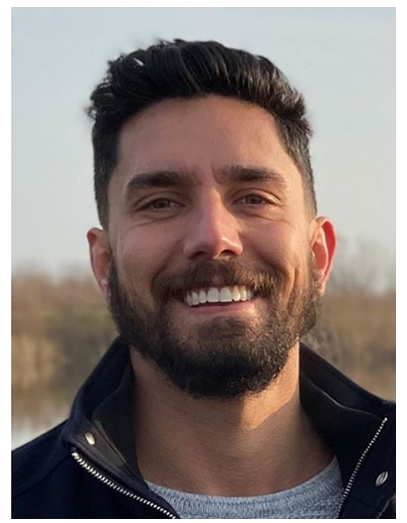

Dr. Carlos Alho is a researcher at Wageningen Environmental Research (Water \& Food Team). $\mathrm{He}$ has a $\mathrm{PhD}$ in Production Ecology \& Resource Conservation from Wageningen University (Soil Biology Group). His current research interests are in food systems transformations that offer inclusive and equitable opportunities for sustainable and healthy food production and consumption. 


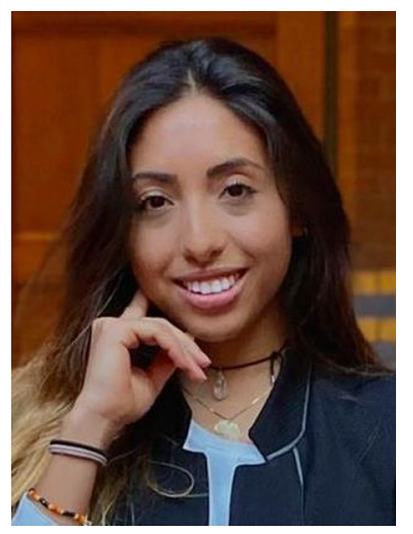

Amanda Francisco da Silva is an independent consultant in Sustainability \& Strategy. She has an MSc in Environmental Sciences from Wageningen University. Her work focuses in developing innovative ways to promote alignment between businesses, social accountability, and environmental responsibility. She is an advocate for sustainable development strategies with expertise in governance in commodities' value chains, specialized in cocoa and chocolate; sustainability design and strategy; stakeholder's management and environmental, social and corporate governance.

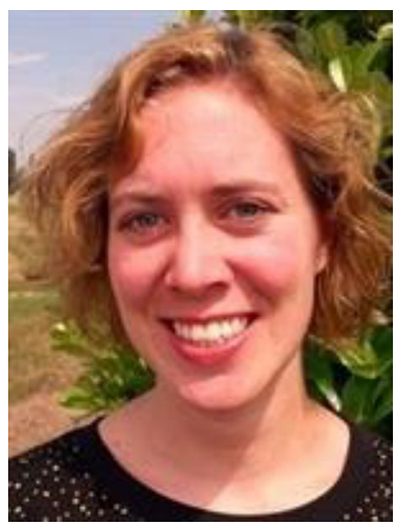

Dr. Chantal Hendriks is a researcher at Wageningen Environmental Research. Her research focusses on nutrient and carbon modelling of agricultural systems at different scales. The projects she is working on support the transition to sustainable agriculture. She did a joint $\mathrm{PhD}$ with Wageningen University \& Research and ICRISAT, where she analysed ways to improve the soil data in regional land use analyses. During her postdoctoral study at the University of Oxford, Chantal was working for the Malaria Atlas Project to study the role of agricultural insecticides on insecticide resistance in malaria vectors.

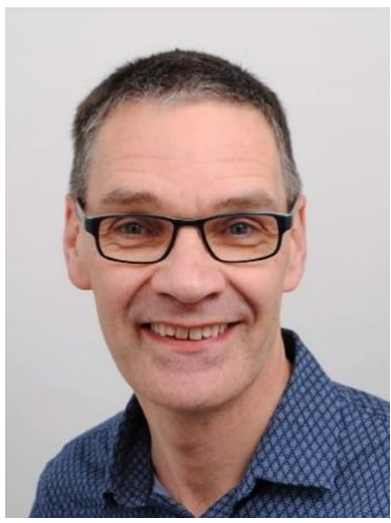

Dr. Jetse Stoorvogel is an associate professor in the Soil Geography and Landscape Group of Wageningen University (Wageningen, the Netherlands) with a special focus on soil-land use interactions with special emphasis on soil geography, soil inventory, GIS, and agronomy. Specific studies focus on global soil degradation (S-World), the impact of urbanization on soil conditions and the role of soil conditions on crop management.

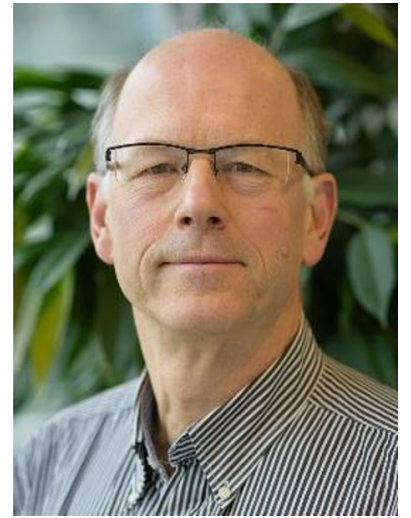

Prof. Dr. Peter Oosterveer is professor at the Environmental Policy Group at Wageningen University, the Netherlands. He has an MSc in rural sociology (1982) and a PhD (2005) from Wageningen University. His research interests are in the sustainable transformation of food systems with a focus on global public and private governance initiatives and innovative institutional arrangements in the field of sustainable food production and consumption. Furthermore, he is researching food consumption practices from a sociological perspective and thereby especially interested in consumer's access to sufficient, sustainable, safe and healthy food.

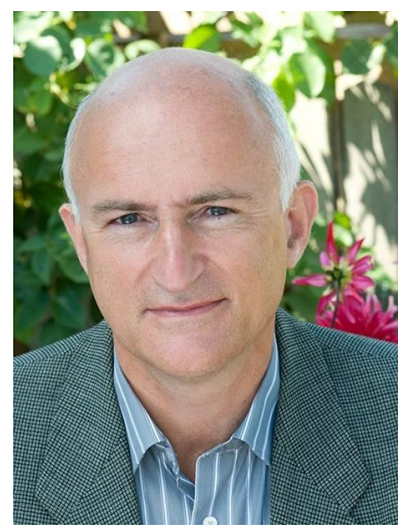

Dr. Eric Smaling is a senior researcher of Wageningen Environmental Research at Wageningen University \& Research. He holds an MSc in soil science and a $\mathrm{PhD}$ in soil fertility management from Wageningen University. Smaling conducted research in soil geography, land evaluation and integrated soil fertility management, mainly in Indonesia, East and West Africa. Between 1997 and 2012, he has been Professor of soil science and sustainable agriculture, first at Wageningen University, later at the University of Twente, Faculty of Geo-Information Science and Earth Observation (ITC). Smaling also worked as free-lance consultant to the World Bank, the Food and Agricultural Organization (FAO), The UN Fund for Environmental Protection (UNEP), Rockefeller Foundation, Bill \& Melinda Gates Foundation, and the CGIAR. He has also been a Senator (2007-2013) and then a Member of Lower House (2013-2017) in the Dutch parliament for the Socialist Party. Since 2017 he joined Wageningen University \& Research again to provide guidance to several large international programs for rural and agricultural development. 